\title{
COMPARING BUDGETARY STRUCTURES AND PROCESSES \\ The cases of Paris and São Paulo
}

\section{Ursula Dias Peres (1)}

E-mail: uperes@usp.br

\section{Camille Allé ${ }_{(2)}$ (DD}

E-mail: camille.alle@sciencespo.fr

(1) Escola de Artes, Ciências e Humanidades da Universidade de São Paulo, São Paulo, SP - Brasil.

(2) Sciences Po Paris, Paris - France.

DOI: $10.1590 / 3610701 / 2021$

\section{Introduction}

Every year, following a permanent calendar, civil servants working in federal, national or subnational administrations begin the same annual budget process. A large machine is set in motion with a number of players following specific routines. Few changes are observed in this process and rigidity is the main rule. Generally, changes are marginal and follow an incremental process. To produce these incremental moves in public administration, the Budget Department, Operational Departments and the executive power go back and forth in deciding on the publication of the annual Budget. As such, the Budget is the result of an annual budgeting process, which is very technical and standardized worldwide. However, budgeting is also a sovereign space of distributive

Artigo recebido em: 26/07/2020

Aprovado em: 20/12/2020 conflict. The stricter the budget, the more complex and disputed is the budget process, with a diversity of players involved (politicians, groups of interest, administrations), who bargain to implement marginal changes in an insufficient public fund. Therefore, the stricter the budget, the higher the distributive conflict among the players.

This paper compares the budgeting revenues and expenditures and the institutional budget structure of two municipalities governing two cities, São Paulo and Paris. A financial bureaucracy description at the municipal level aids in understanding budgetary decisions and contributes to the budget literature, more focused on national and federal levels.

Despite the disparities between both cities, according to their technical and standardized public budget characteristics, one should observe similar budgeting structures and processes. However, the present comparison indicates differences within similarities as both cases, with very different macro 
institutions (federal versus unitary States), similar mesoinstitutions (organization of municipal institutions, municipal public policies, budget planning), but certain different rules, generate important differences in their processes and some divergence in their results.

If, on the one hand this demonstrates that budgetary incrementalism may explain some similarities between the two cases, on the other, this comparison also highlights that budgeting structures and processes are not totally standardized. One of the largest differences between Sao Paulo and Paris is the volume of municipal revenue per inhabitant and its dynamics. As the political and economic capital of a rich country, Paris works with a higher level of public revenue per inhabitant. Another difference, linked to the first one, is the budget volume that can be allocated by municipal governments to invest in new projects. For different reasons, such as earmarked revenues, an institutional definition for municipal budgets in Brazil, and others explained in the article, this discretionary capacity to invest is more important in Paris than in São Paulo. This, in turn, also impacts the budget process: as the volume of the municipal budget negotiated and dedicated to marginal changes is lower, budgeting negotiations may lead to higher conflict in São Paulo. São Paulo’s mayor, despite governing the wealthiest city in Brazil, has to deal with a small discretionary amount of the annual budget and solve a complex distributive conflict among several groups of interests. Paris' mayor, despite governing a capital in a unitary country, seems to have more autonomy than the mayor of Sáo Paulo in a federal one.

To present this comparison, this paper is categorized into four sections, in addition to the introduction and the conclusion. Section 2 presents the theoretical framework and methods. Section 3 describes the macro-institutional rules and points out the main administrative and political differences between the two cities. Section 4 provides the details of the responsibilities of São Paulo and Paris in offering local public policies. Section 5 compares budgeting expenses and revenues of the two cities in the past years, highlighting the main characteristics of the budget process and governance, such as hierarchy, inertia and negotiation, that support budgetary incrementalism. The conclusion synthesizes the main results and outlines future investigations.

\section{Theoretical Framework and Methods}

\section{Literature review}

The literature on the budget process has been influenced by Wildavsky's publications in the sixties and seventies (Wildavsky, 1964, 1969, 1975). While incrementalism was defined by Lindblom (2009) as a general decision-making process, Wildavsky defined this concept in the context of public budgeting as a process in which budgeting bases (previous and inherited expenditures) are accepted and decisionmaking is focused on the "increment" defined as the small part of the budget that changes from the base. As a result, political attention is focused on a tiny part of the budget. Moreover, the conflict between players involved in the budget process is more intense and concentrated on the increment. Occasionally, new factors, such as severe scarcity (Schick, 1976, 2009), a political crisis, or a broad political party coalition may alter the incremental process and redefine the budgeting allocation, as analyzed by Baumgartner and Jones (1993). However, these changes will tend towards a new equilibrium and expenditures will probably grow again incrementally (Baumgartner et al., 2011).

As noted by Berry (1990), many budgetary incrementalism definitions have been produced. Different scholars have attempted to demonstrate whether public budgets were incremental or not, based on quantitative data and an economic approach. In this paper, the aim is to compare the budgeting revenues and expenditures of two different cities and their institutional budget structures. Budgetary incrementalism is defined herein as a slow budgetary growth process characterized by the protection and rigidity of the largest part of the budget ("the base") and a strong competition among players concerning to the discretionary part of the budget ("the increment").

To complete this classical budgetary incrementalism definition, we also use the literature on budgetary governance that demonstrates how budget and budget processes assessments are important to understand 
public policies and politics (Bezes and Siné, 2011; Shick 1976). Governance is generally defined as the process used to coordinate individual players and groups to achieve certain common goals. The notion of budgetary governance also takes into account the macro and micro characteristics of the budget process. Indeed, the macro-institutional arrangements specific to each country (a Federal or Unitary structure of State, Federal or national financial rules and constraints, responsibility distribution between Government levels, among others.) and micro-institutional arrangements described below constitute formal and informal rules that induce and are induced by Governmental and non-Governmental player behavior (Marques, 2013). This article demonstrates how these macro and microarrangements strengthen budgetary incrementalism and argues that budgetary incrementalism explains the slow evolution of local public budgets and their rigidity. The micro-arrangements that characterize the budget process reinforce this slow and marginal change process (see Table 1), detailed below.

The budget process is complex. It implies in monitoring financial resources and spending in order to produce trends, forecast budgeting evolution. All these relatively abstract flows are reported in tables, software and budgeting reports and follow a regular annual calendar. Part of this complexity is also a

Table 1

Budget process and (un)change factors characteristics

\begin{tabular}{cc}
\hline $\begin{array}{c}\text { 1) Complexity of budgetary } \\
\text { rules (instruments) }\end{array}$ & $\begin{array}{c}\text { Core, 2007; Bezes and } \\
\text { Siné, 2011; Lascoumes } \\
\text { and Le Galès, 2012 }\end{array}$ \\
\hline $\begin{array}{c}\text { 2) Hierarchical budgetary } \\
\text { organization and budget } \\
\text { bureaucracy influence in } \\
\text { decision making }\end{array}$ & $\begin{array}{c}\text { Miller, 1992; Peres, } \\
\text { 2007 and 2018 }\end{array}$ \\
\hline $\begin{array}{c}\text { 3) Inertia in the allocation of } \\
\text { resources }\end{array}$ & Hayward, 1976; Peres, \\
2018 \\
\hline 4) Negotiation and muddling \\
through & $\begin{array}{c}\text { Lindblom, 2009; } \\
\text { Wildavsky, 1975; } \\
\text { Wildavsky and Caiden, } \\
\text { 2004 }\end{array}$ \\
\hline $\begin{array}{c}\text { 5) Discretionary power of } \\
\text { politicians to allocate a small } \\
\text { part of financial resources }\end{array}$ & $\begin{array}{c}\text { Jones et al., 1998; } \\
\text { Baumgartner et al., } \\
\text { 2011; Peres, 2018 }\end{array}$ \\
\hline
\end{tabular}

Prepared by the authors. consequence of a great number of rules and fiscal laws that Governments must obey. Especially concerning local finance, these rules are set forth by federal or central Governments and also by international institutions, such as the European Community and the IMF among others. Fiscal austerity has been a goal everywhere in past decades. Rule overlapping has led to a very complex public budget, incomprehensible to common people and even to members of Governments who are not directly involved in the budget process.

As a result of this complexity, the Budget Department is a very strategic one, as it is responsible for all revenue forecasts and fiscal equilibrium. The expenditure allocations in healthcare, education or urban services depend on these forecasts. Budgeting allocation is a political power for the mayor (Fuchs, 1992), which places the Budget Department hierarchically above all other Government Departments. As budgeting rules are complex, few are interested in this domain. This implies that budgeting decisions to implement public policies are established by a budgeting board, essentially comprised of few people, i.e., administrative experts and very few politicians trusted by the Mayor. In general, no discussion on the number of resources or their allocation is currently occurring in an open arena. Bilateral discussions prevail among the Budgeting Board and other Departments.

If its complexity and hierarchy make the budget process difficult to understand, it also prevents an open participation in the decision-making process. Within the executive branch, among Mayors and Deputy-Mayors, few people decide on tax policies and expenditure allocation, except the Mayor and their Deputy-Mayor of finance. This tends to prevent great punctuations and increase incremental growth.

In addition, another feature reinforces the status quo: inertia. The withdrawal of expenditures from the general budget is still more difficult than its approval. The budgeting accommodation, defined as a relation created between expenditure and its beneficiaries and suppliers, and the protection of existing contracts and financial commitments, such as earmarked expenditures, debt and long-term service contracts, among others, restrict a large part of the available budget, making it prone to incremental growth. Part of these expenditures grows due to specific legal rules, while another part grows simply due to the inertia 
of organizations that renew contracts and services without evaluating their ongoing necessity.

Therefore, these features (complexity, hierarchy, and inertia) are present in the budget process and contribute to making it resistant to change. Changes in the budget process tend to be an accommodation of the annual increment to the already existing expenses and only a small part will be allocated in new expenses. This accommodation process, described by Lindblom (2009) as "muddling through", depends on the interaction of budget spenders (Operational Departments) and guardians (Budget Department) that negotiate and bargain regarding the possibility of expanding programs or creating new ones ${ }^{1}$. A great part of the budget will remain at the same level as the previous year, and only a small part will incrementally move forward (Wildavsky, 1975).

On occasion, however, this trend may be broken. Punctuations (important variations of the spending volume allocated to a public policy or resources) may take place. To explain these variations, Jones and Baumgartner (2005) proposed a punctuated equilibrium theory. According to these authors, the status quo and incremental change are the norm. However, when policymakers face urgent and mediated problems, a peak of attention on a specific issue may arise, implying in the allocation of more public money to solve it. Usually, when this occurs, some financial turbulence that shakes the usual budgeting accommodation until another one takes place is noted. A rupture in incrementalism may occur during this process. According to Schick (1976), different levels of scarcity may lead to this rupture.

Whether through an incremental process or punctuation, it is necessary to highlight the importance of the Mayor and the Mayor's discretionary power. As the budget process is complex and tied with fiscal rules, the allocation of the small part of the increment is a very important and symbolic issue. This current political decision contributes to budgetary austerity, such as past allocation choices. The limits of the Mayor's discretionary power depend on different variables, such as the financial capacity of the city (mostly tax police), existence of earmarked revenues, budget rigidity with past allocations (existing contracts that cannot be terminated) and indebtedness. Different
Mayors from different political wings may handle these variables in different ways.

In this context, this paper analyzes the differences and similarities of budgeting revenues, expenditures and institutional budget structures of the municipalities of Paris and São Paulo.

\section{Methods}

Two very different cases were selected for research on similar processes (Seawright and Gerring, 2008). The first comprises the municipality of São Paulo. Located in a federal country in South America, this economic capital is experiencing an overall growth of its population, the development of economic activities and thereby, increasing demands for infrastructure and public services (transportation, water supply, waste management and healthcare, among other services). The second is the city of Paris, located in a unitary state in Europe and both the political and economic capital of France.

Regarding the municipality of São Paulo, the information resources for this study include data on municipal revenues and expenditures based on official balance sheets from 2003 to 2018 , in addition to a documentary analysis concerning legislative budget processes. Regarding Paris, the data is based on an analysis of the city budget from 2008 to 2018 (from the beginning of a new city mandate to the latest data available) and interviews with civil servants. Paris data has been converted into Brazilian Reais (R\$) using purchasing power parity. Both authors have been employed by the local authority (as a manager of the São Paulo municipality budget and as a tax adviser in the Paris city Budget Department). The analysis is also based on direct observation. The main characteristics of both cases are pointed out in Table 2 .

A quick look concerning municipal finance demonstrates important differences, as shown in Table 3 . The Paris budget is approximately $\mathrm{R} \$ 37.5 \mathrm{~B}(€ 8.5 \mathrm{~B})$ in 2018 , about $R \$ 9,390$ per inhabitant $(€ 3,500)$. The second city of France, the Great Lyon, which has similar competences, spent approximately $\mathrm{R} \$ 7,000$ per inhabitant in $2018(€ 2,600)$. This difference can be explained by the role that Paris plays as the national capital. The São Paulo budget is approximately $\mathrm{R} \$ 59.55 \mathrm{~B}(€ 11 \mathrm{~B})$ in 2018 . Considering expenditures 


\section{Table 2}

Macro-institutional characteristics of both cases

\begin{tabular}{|c|c|c|}
\hline \multirow{2}{*}{ State Structure } & Sáo Paulo & Paris \\
\hline & Federal & Unitary State \\
\hline Administrative Decentralization & $\begin{array}{l}\text { Mandatory local public services and } \\
\text { political responsibility }\end{array}$ & $\begin{array}{c}\text { Mandatory local public services and } \\
\text { political responsibility }\end{array}$ \\
\hline Political Decentralization & $\begin{array}{l}\text { Elected Executive and legislative } \\
\text { powers/ constitutional autonomy }\end{array}$ & $\begin{array}{c}\text { Executive power elected indirectly by } \\
\text { citizens }\end{array}$ \\
\hline \multirow[t]{3}{*}{ Financial Decentralization } & $\begin{array}{c}\text { Partial Budgetary Autonomy: } \\
\text { budgetary laws \& earmarked funds }\end{array}$ & $\begin{array}{l}\text { Budgetary Autonomy: annual budget } \\
\text { and mandatory competences }\end{array}$ \\
\hline & Very Partial Fiscal Autonomy & Partial Fiscal Autonomy \\
\hline & No Bank Autonomy (access to credit) & Bank Autonomy (access to credit) \\
\hline \multirow[t]{5}{*}{ Two economic capitals } & $\begin{array}{c}\text { Limited access to the State } \\
\text { administrations and to the Federal } \\
\text { Government }\end{array}$ & City-State \\
\hline & $\begin{array}{l}\text { High pressure from companies and } \\
\text { other interest groups. }\end{array}$ & $\begin{array}{l}\text { Privileged access to the State } \\
\text { administrations and to the } \\
\text { Government + specificities of Paris } \\
\text { (city + department/metropolis, region) }\end{array}$ \\
\hline & \multirow[t]{2}{*}{$\begin{array}{l}\text { Distributive Conflict over Public } \\
\text { Funding (limited funding) }\end{array}$} & High pressure from companies \\
\hline & & And other interest groups. \\
\hline & $\begin{array}{l}\text { Distributive Conflict over Public } \\
\text { Funding (limited funding) }\end{array}$ & $\begin{array}{c}\text { Distributive Conflict over Public } \\
\text { Funding (different funding possibilities } \\
\text { compared to São Paulo) }\end{array}$ \\
\hline
\end{tabular}

Prepared by the authors.

Table 3

Budget per inhabitant in São Paulo and Paris

\begin{tabular}{cc}
\hline Sáo Paulo & Paris \\
\hline $\mathrm{R} \$ 59.5 \mathrm{~B}$ & $\mathrm{R}$ \$ 37.5 B \\
\hline $\mathrm{R}$ \$ 4,500 per inhabitant & $\mathrm{R} \$$ 9,390 per inhabitant \\
\hline
\end{tabular}

Prepared by the authors based on 2018 Budgetary Reports for both cities.

per inhabitant, the volume is only $\mathrm{R} \$ 2,260$ (€ 850), much lower compared to Paris.

In a similar manner to Paris, São Paulo benefits from its economic power and from tax levied on services and properties. Both cities depend more on local income than on federal or state grants.

\section{Macro-institutional arrangements}

The budget processes of both São Paulo and Paris municipalities are framed by macro-institutional rules, comprising the political-administrative structure and the division of financial resources between Governments levels.

\section{Organization of subnational Governments}

The political administrative structure is an important difference between both countries, since Brazil is a federal State and France is a unitary State. Brazil is categorized into States and each State is divided into municipalities, where both the states and the municipalities have administrative and political responsibilities defined by the Constitution Law of 1988. The State governor and the municipality Mayor are both elected and govern with an elected legislative power, comprising local councils and state assemblies. In France, subnational Governments are much more complex. The State is divided into regions, comprising several departments. In each department, metropolis or inter-municipalities cluster distinct municipalities. Each level is governed by a council composed of elected persons that exercises specific 
administrative responsibilities, such as urbanism and metropolis and inter-municipality planning, and manages its own budget.

Nevertheless, both countries have experienced an incremental decentralization process since the 70/80s. In France, a financial decentralization was engaged at the end of the 70s (Le Galès, 2006; Le Lidec, 2011; Allé, 2017; Douillet and Lefebvre, 2017). Local taxes (property tax, land tax, local business tax) were created and subnational authorities had the possibility of voting on the rates of these taxes. A political decentralization (direct election of subnational authorities) and an administrative decentralization (transfer of competences from the Central State to subnational authorities) followed. In Brazil, the new Constitutional Law in 1988 promoted the empowerment of cities that were becoming federal units (Arretche, 2012). In Brazil, as in France, the transfer of administrative and political responsibilities in different public policy areas was incremental.

\section{Funding administrative responsibilities}

Local public policies implemented by subnational Governments are funded with distinctive margin of discretion concerning resources. In Brazil, revenue allocation is highly earmarked, which is not the case in France. Brazilian municipalities must spend a fixed part of their tax resources to fund certain public policies, (education, healthcare, transportation). This constraint secures the funding of federal priorities. In France, subnational authorities have mandatory responsibilities to ensure. For instance, municipalities and inter-municipalities must fund waste management, although they decide on how to organize this public policy and how much it costs.

The existence of national reference services in Brazil, such as healthcare and transportation, with imposed local funding, can lead São Paulo’s Government to a more intense budget process dispute compared to Paris, in order to allocate the remaining part of public resources. In Brazil, the dispute is concentrated on the remaining portion of public resources, after education and healthcare, whereas in France, as no earmarked public fund are available, the dispute seems more diffuse.
In both cities, the competition for funds and services becomes more complex due to citizen difficulty in understanding who is responsible for which service. In São Paulo, these may be either the state (departments) or the municipality, while in Paris, in addition to the city, many public authorities intervene. Moreover, in both cases, Government sublevels within the municipality also exists. In São Paulo, Sub-Municipalities are managed by Sub-Mayors, who are not elected. In Paris, district (or borough) councils are comprised of politicians directly elected by citizens living in each borough. Each one of the 20 district councils elects a district Mayor, which is the reference for very local issues. They are responsible for very local public services and investment projects (for example, reorganizing public gardens or areas). In both countries, borough councils are administrative organizations with few budgeting resources.

In terms of resources, cities in Brazil have the autonomy to collect local taxes, as provided in the Federal Constitution of 1988 and the Domestic Revenue Code. They cannot create new taxes, but they may alter tax rates. This is, however, unlikely to occur in most municipalities as $90 \%$ of them have a very low tax base. Brazilian municipalities are highly dependent on current transfers from the Union and States. In approximately $80 \%$ of Brazilian cities, grants accounts for $90 \%$ of the global collection. In France, tax autonomy varies between subnational Government levels. For municipalities, financial resources are, on average, composed of $40 \%$ local taxes (which local authorities have a power to adjust), $10 \%$ of sharing taxes (no power to adjust), 20\% of grants from the National State and $30 \%$ of savings or other resources (tariff revenues, subsidies from department and region, among others. $)^{2}$. Moreover, subnational authorities in France can use credit and bank operations without requiring previous State authorization, while Brazilian municipalities depend on a National Treasury (STN-MF) analysis and Federal Senate authorization.

The next section presents the responsibilities of the municipalities of São Paulo and Paris, which are important to understand their budget structure. 


\section{Municipal public policies and responsibilities in Sáo Paulo and Paris}

Municipal budget structures partially depend on polities, the political responsibilities of public organizations and implemented public policies. Polity, the structure of municipal organization, contributes to organize the role division between players. For example, the Mayor and Deputy-Mayor selection mode has an impact on their discretionary powers during the budget process. Therefore, municipalities have different responsibilities, where some are mandatory (they must produce a certain public policy) and others are optional and discretionary. Finally, in order to implement public policies, public funding is required to produce the policy or to fund the companies to produce it, which becomes financially translated into public accounts and the public budget. This section describes the polity structure of São Paulo and Paris, their public responsibilities, and the most important municipal public policies in terms of budgeting amounts.

\section{How are the municipalities of São Paulo and Paris governed?}

Both São Paulo and Paris are the political and economic centers of their respective countries. The Table 4 below sums up the main differences between the two cities.

São Paulo, the capital of the state of São Paulo, is the largest city in Brazil and South America, with a state-size budget and an estimated population of 12 million inhabitants. Despite its vitality, São Paulo's disordered growth and past allocation decisions have resulted in significant deficits in services concerning key policies, such as early childhood education, basic healthcare, urban mobility, and housing. Ever since the democratization process, the city of São Paulo has been the stage for fierce political disputes for the municipal executive, with high alternation of power,

Table 4

Sáo Paulo and Paris political institutions

\begin{tabular}{|c|c|c|}
\hline & Sáo Paulo & Paris \\
\hline The Mayor & $\begin{array}{l}\text { Directly elected by citizens } \\
\text { (the first-past-the-post system) }\end{array}$ & Elected by the Municipal Council \\
\hline \multirow[t]{2}{*}{$\begin{array}{l}\text { Vice-Mayors or } \\
\text { Secretaries }\end{array}$} & Revocable secretaries appointed by the Mayor & $\begin{array}{l}\text { Appointed by the mayor, among municipal } \\
\text { councillors. }\end{array}$ \\
\hline & & $\begin{array}{l}\text { Vice-mayors benefit from a delegation of power } \\
\text { from the Mayor to manage sectoral public } \\
\text { policies }\end{array}$ \\
\hline \multirow[t]{2}{*}{ Municipal Council } & Elected by citizens (proportional vote) & Elected by each district council. \\
\hline & $\begin{array}{l}\text { Municipal councillors make up the legislative } \\
\text { branch and vote the municipal budget. }\end{array}$ & $\begin{array}{l}\text { Municipal councillors deliberate (including on } \\
\text { the budget), but do not have legislative power }\end{array}$ \\
\hline \multirow[t]{3}{*}{$\begin{array}{l}\text { Sub municipalities } \\
\text { or Boroughs }\end{array}$} & $\begin{array}{c}\text { thirty-two sub mayors appointed by the Mayor } \\
\text { who manage a reduced local budget authorized } \\
\text { by the Mayor }\end{array}$ & $\begin{array}{l}\text { Twenty submayors indirectly elected: they are } \\
\text { appointed by district councillors of each of the } \\
20 \text { boroughs }\end{array}$ \\
\hline & & $\begin{array}{l}\text { District councillors are elected by citizens of } \\
\text { each Borough/district (proportional vote) }\end{array}$ \\
\hline & & $\begin{array}{l}\text { Each district manages a small budget dedicated } \\
\text { to very local issues (maintenance of elementary } \\
\text { schools, libraries, gymnasiums, among others) }\end{array}$ \\
\hline Political orientation & $\begin{array}{c}\text { Alternation of power } \\
\text { (left wing and center-right wing) }\end{array}$ & Socialist since 2001 \\
\hline
\end{tabular}

Prepared by the authors based on Budgetary Reports for both cities and laws. 
alternating between center-left, center and centerright (Marques and Hoyler, 2018). The existence of political contention maintains a fierce distributive conflict among groups of power, forcing a discussion on public funds (Schneider, 2005). The Mayor is responsible for the entire city budget. Although São Paulo also has 32 Sub-Mayors, they are not elected, being appointed by the Mayor, who also authorizes their budgets. The Sub-Mayors are local references for certain services, such as janitorial and street cleaning maintenance.

As Paris is the largest city in France, it concentrates inhabitants and companies and is the city's financial center. Paris is also where the Central State (Executive Government, Parliament and Central Administrations) is established. Dating back to the Old Regime, the central Government was very suspicious of the political authorities in Paris, deemed as potentially insurrectional, which partially explains why Paris has a specific political status. Until 1975, Paris was not ruled by a Mayor but by the central State. In 1975 , a new law instituted the election of city councillors who in turn, elect a Mayor. In 1982, another law created a specific status for the three largest cities in France, Paris, Lyon, and Marseille. These cities were divided into districts (or boroughs), each comprised of a district council with a Mayor. According to a proportional representation list system, citizens vote for a list of district councillors and some of them join the Council of Paris (a deliberative assembly that debates and votes on most of decisions). Each district handles its own budget for basic infrastructure and very local issues. For several years, Paris was both a municipality and a department with two budgets. In 2019, the municipality and the department were merged into one single authority, the "city of Paris". The Mayor of Paris is still elected by the Council and this new entity still has the same competences. A single budget was adopted. After several years of right-wing municipal Government (1975-2001), since 2001, socialists have governed the municipality. When beginning their mandate, the Mayor of Paris appoints Deputy-Mayors among elected councillors, which is an important difference compared to São Paulo, where secretaries are not elected but appointed by the Mayor as employees who may be dismissed.
Each one is responsible for a domain of public services and has the capability to arbitrate issues. The first Deputy-Mayor oversees the Budget and is the Mayor's right-hand.

\section{What are the cities of São Paulo and Paris in charge of?}

Paris has similar responsibilities to other French cities and departments (Table 5). Most of the competences summarized below are mandatory. In fact, local authorities must implement public services in several domains, as provided by law. However, local politicians decide which level of public services they want to provide, and, unlike Brazil, they are not obliged to dedicate a predetermined part of the budget to these public services.

The stability of municipal responsibilities and of the polity organization contributes to the stability of players involved in the budget game. Indeed, practices of working together, long-term contracts and pluriannual public policies, among others, are easier to implement when the main city organization characteristics remains stable. Indirectly, it contributes to close off the budget game to only a small number of players.

As displayed in Table 5, both São Paulo and Paris are responsible for a wide range of public policies. However, in São Paulo, as in other Brazilian municipalities, a mandatory responsibility for education and health policies is observed. In Brazil, these policies have been systematized and controlled by the federal government over the last few decades, especially since the 1988 Constitution, with a national definition of expenditure rules and a division of tasks between subnational governments. In addition, the Constitution defines that these policies are funded with earmarked revenues at the local level, i.e., at least $25 \%$ of local taxes must finance education and at least $15 \%$ should be destined to healthcare ${ }^{3}$.

Therefore, the national systematization of these policies determines that a good part of the annual budget resources of the local government shall be used in the municipalization of children's elementary and education and in primary healthcare, in addition to financing specialties and hospitals. Although the 


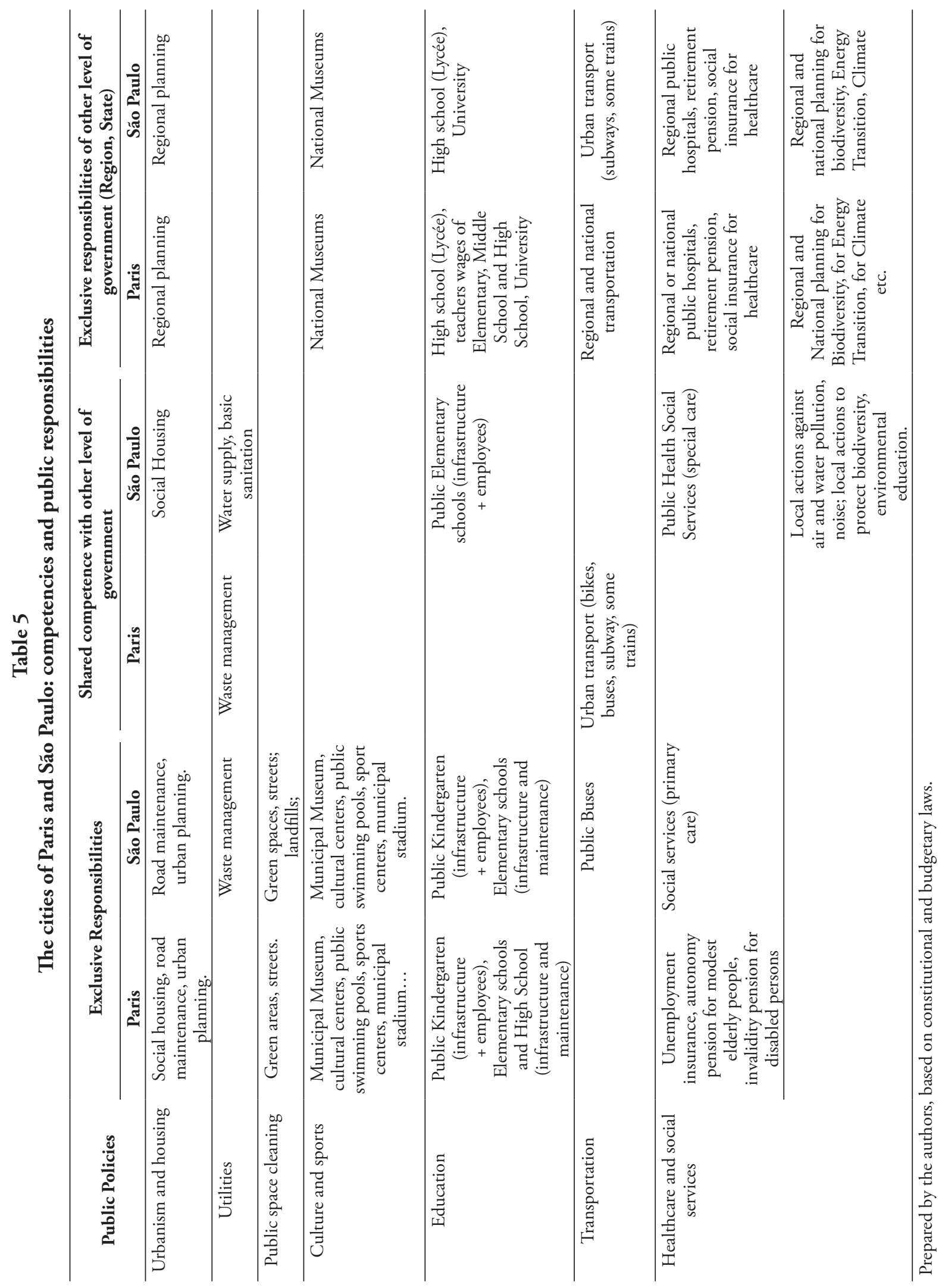




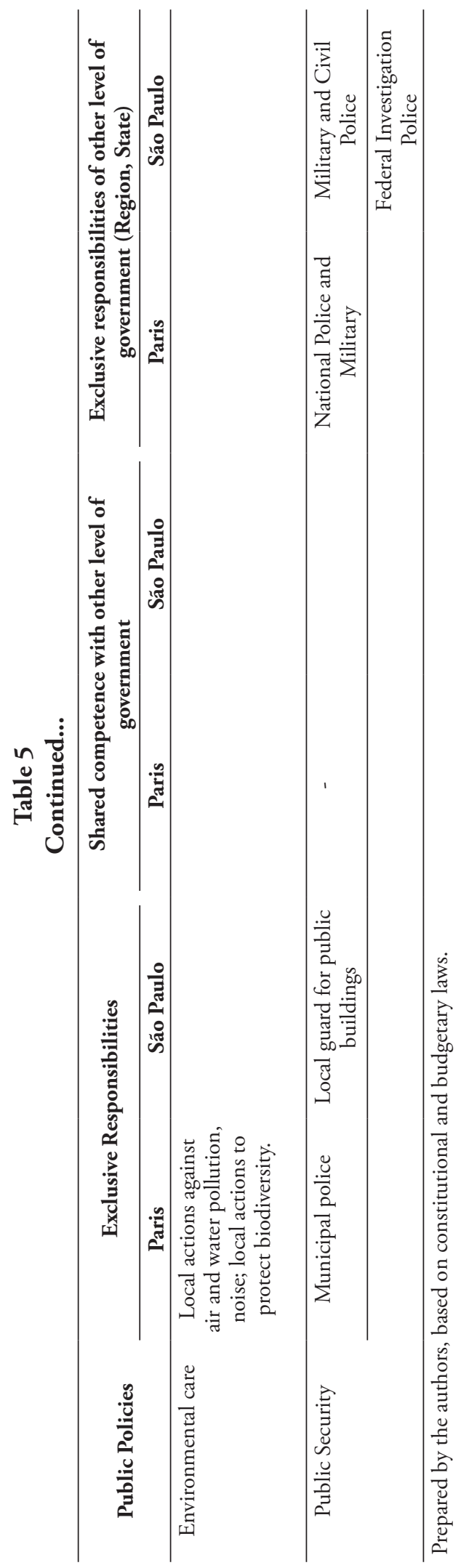


federal government transfers funds to both areas, they do not reach 15\% of São Paulo's expenditures São Paulo.

Paris is also responsible for a part of education and social policies, but the city is not constrained to spend a defined portion of local taxes. Except for minimum social incomes, that are mandatory spending, the city decides how much funding is spent in these policies. This is less restrictive concerning the budget management.

\section{Expenses and revenues: Between rigidity, incremental growth, and discretionary decisions}

Despite all the previously described differences, the budget processes and structure of both cities share some similarities. This partially demonstrates how budgeting micro-arrangements support budgetary incrementalism. After focusing on the more constraining contexts of budgetary dialogues in both cities, this part explains the budget process, its players and rules. Therefore, this section compares the structure of São Paulo and Paris's expenses and income, and their evolution over the years.

\section{A context of further constraints}

São Paulo and Paris are currently facing greater control of their finances, even though budget constraints are much more important in the former than in the latter. In São Paulo, fiscal responsibility and accountability, as well as the efficient and effective use of resources, have become important symbols for society since 2000 . The municipality is facing a contradictory move. On the one hand, social leaders require more information and more local public policies while, on the other, budgetary austerity is growing since indebtedness is not allowed and the public deficit is strictly controlled, steering the demands. Increased budgetary austerity led to a reduction of the incremental portion of the budget that could be discussed. This brings the city to a chronic revenue scarcity syndrome, even with revenue growth (Schick, 1976).
To face the increasing profusion of tasks that must be accomplished in São Paulo, the municipal administration must adapt. It currently comprises 27 Secretaries, two Foundations, 11 Governmentowned companies, 17 Funds, and 32 Districts, all of which implement their own budgets. Great part of São Paulo's budget is allocated for the payment of pre-defined activities (ones with constitutional or legal support). These administrative structures precede the preparation and discussion of the budget arena, adding to budgetary austerity.

In France, national rules are less directly constraining, even when framing interactions between players in the budget process. In Paris, budgeting constraints have become increasingly more important since the 2010s, as cuts to grants allocated by the Central State (20142017) and, now, the limitation of annual operating spending increases are limiting the global budgeting trend. However, Paris remains as the rich capital of the country. This status produces many financial resources, such as tourism, real estate revenue and State investments. Moreover, the economic and financial crisis is much less severe than in São Paulo, and the lack of a dynamic demography implies in reduced need for social services. Similar to São Paulo, the Parisian administration is comprised of 26 Administrative Departments (finance, economics, environment, housing, urbanism). Moreover, the city provides financial support to 18 public-private companies (public and private investors) and government-owned companies (only public investors) to produce services or public goods, such as social and private housing, offices, urban heating, public planning and urbanism and funeral services, among others.

\section{Budgeting: A very hierarchical process}

The budget process involves both political and administrative players, and, even at the toplevel management, the lines are not that clear. The Table 6 below compares the political-administrative framework that drives the budget process in both São Paulo and Paris. In both cities, Budget Departments carry out similar activities, i.e., planning the budget, forecasting expenses and revenues, coordinating the budgeting demands for other Departments 
Table 6

Comparison of the political and administrative hierarchies that drive the budget process

\begin{tabular}{|c|c|c|}
\hline & Sáo Paulo & Paris \\
\hline \multirow[t]{7}{*}{ The top budget management } & & No structuring, but a plurality of players: \\
\hline & $\begin{array}{l}\text { Formal structure called the Financial and } \\
\text { Budgetary Board (JOF): comprised of } \\
\text { four departments (finance, government, } \\
\text { administration, and justice), the JOF } \\
\text { makes all decisions on spending and } \\
\text { revenues parameters. }\end{array}$ & $\begin{array}{l}\text { - the Mayor and their office (political } \\
\text { councillors). }\end{array}$ \\
\hline & & $\begin{array}{c}\text { - the deputy-mayor of Finance and their } \\
\text { office; }\end{array}$ \\
\hline & $\begin{array}{l}\text { The four Members of the JOF are } \\
\text { appointed by the Mayor. }\end{array}$ & $\begin{array}{l}\text { - the General Secretariat (involved in all } \\
\text { transversal subjects); }\end{array}$ \\
\hline & & $\begin{array}{l}\text { - the Director of the Department of } \\
\text { Finance (administrative); }\end{array}$ \\
\hline & & $\begin{array}{c}\text { - Sectorial deputy-mayors: they intervene } \\
\text { in the budget process but only have certain } \\
\text { influence over it; }\end{array}$ \\
\hline & & $\begin{array}{l}\text { - Sub-mayors: they intervene to defend } \\
\text { their Sub-municipal budget. }\end{array}$ \\
\hline \multirow[t]{2}{*}{$\begin{array}{l}\text { The Municipal Council and } \\
\text { its Commission in charge of } \\
\text { Finance }\end{array}$} & $\begin{array}{l}\text { Deputies amend the project of Law in the } \\
\text { Economics commission, during bilateral } \\
\text { negotiations and during the Public Debate. }\end{array}$ & \multirow{2}{*}{$\begin{array}{l}\text { Political groups formed by municipal } \\
\text { councillors can marginally amend the } \\
\text { budgetary project during the Financial } \\
\text { commission or negotiate bilaterally. }\end{array}$} \\
\hline & $\begin{array}{l}\text { The most important political players in } \\
\text { this negotiation are the budget rapporteur } \\
\text { and the government leader. }\end{array}$ & \\
\hline \multirow[t]{6}{*}{$\begin{array}{l}\text { The Budgetary Department } \\
\text { ("savers") }\end{array}$} & $\begin{array}{l}\text { The Sub-Secretariat of Planning and } \\
\text { Municipal Budgeting (SUPOM) is part of } \\
\text { the Finance Secretariat and: }\end{array}$ & $\begin{array}{l}\text { The Sub-Department of the Budget is } \\
\text { part of the Department of Finance and } \\
\text { Procurement and: }\end{array}$ \\
\hline & $\begin{array}{l}\text { - Is responsible for setting deadlines for } \\
\text { the preparation and implementation of the } \\
\text { budget, }\end{array}$ & $\begin{array}{l}\text { - Is responsible for setting deadlines for } \\
\text { the preparation and implementation of the } \\
\text { budget; }\end{array}$ \\
\hline & $\begin{array}{c}\text { - Coordinates the work of the Planning } \\
\text { and Budgeting Centers of all municipal } \\
\text { bodies; }\end{array}$ & $\begin{array}{c}\text { - Coordinates the budgetary planning and } \\
\text { forecast with other departments of the } \\
\text { municipality; }\end{array}$ \\
\hline & $\begin{array}{l}\text { - Provides bureaucratic support to the } \\
\text { JOF; }\end{array}$ & - Produces all legal documents; \\
\hline & - Produces all legal documents. & - Produces financial analysis for the office; \\
\hline & & $\begin{array}{c}\text { - Produces annual and pluriannual } \\
\text { forecasts. }\end{array}$ \\
\hline \multirow[t]{2}{*}{$\begin{array}{l}\text { Other Departments } \\
\text { ("spenders") }\end{array}$} & $\begin{array}{c}\text { Twenty-seven Secretariats: Department of } \\
\text { Health, Department of Education, among } \\
\text { others. }\end{array}$ & \multirow{2}{*}{$\begin{array}{c}\text { Twenty-five Departments: Department } \\
\text { of urbanism, Department of social aid, } \\
\text { Department of Housing, Department } \\
\text { of Sports, Department of Economic } \\
\text { Activities, Department of Culture, among } \\
\text { others. }\end{array}$} \\
\hline & Thirty-two Sub municipalities. & \\
\hline
\end{tabular}

Prepared by the authors, based on constitutional and financial laws, decrees and ordinances of both countries and interviews. 
and producing official documents. The role of the Municipal Council and its commission in charge of economics and finance is also very similar in both cases. However, the organization of the top budget management is formally structured by the Financial and Budgeting Board (JOF) in São Paulo and more diffuse in Paris. In both cases, the Mayor deliberates on issues that cannot be resolved.

The budget process is marked by different moments of deliberative decision-making. In both cities, six or seven negotiation and decision steps can be identified. For each step, the players involved attempt to solve as many issues as possible, following the principle of subsidiarity. In case of disagreement at the lowest hierarchy level, the issue is transferred to upper management for analysis and decision. If they disagree, it is then transferred to the next level of upper management, until they reach an agreement, as summarized in Figure 1.

The budget process starts with a budgeting forecast for 3 or 4 years (Step 1). In São Paulo, this pluriannual phase (PPA) is a specific law voted during the first year of the mandate and implemented during the next four years, 3 years of the mandate and the $1^{\text {st }}$ year of the next Mayor. Formulated from January to September, the budget is analyzed and voted by the Municipal Council by December. This pluriannual phase allows the Government to define the guidelines for the Annual Budget. In Paris, a pluriannual budget is also produced. It is, however, redefined each year between December and February and is not voted by the Municipal Council. During these three months, the Budget Department asks other sectoral Departments to detail their spending and revenue forecast for the next 3 years. With all the data, the Budget Department creates a global financial forecast, integrating constraints, such as the limitation of operating expenditures and debt ratios, among others, reaching an amount of unsolvable spending, which entails in finding savings. Resources are not the first instrument used to adjust the budget, as it is more politically sensitive to increase local taxes than to limit the expenditure growth. Each sectoral expert negotiates with their correspondents in the operating

Figure 1

The budget process of the cities of Sáo Paulo and Paris

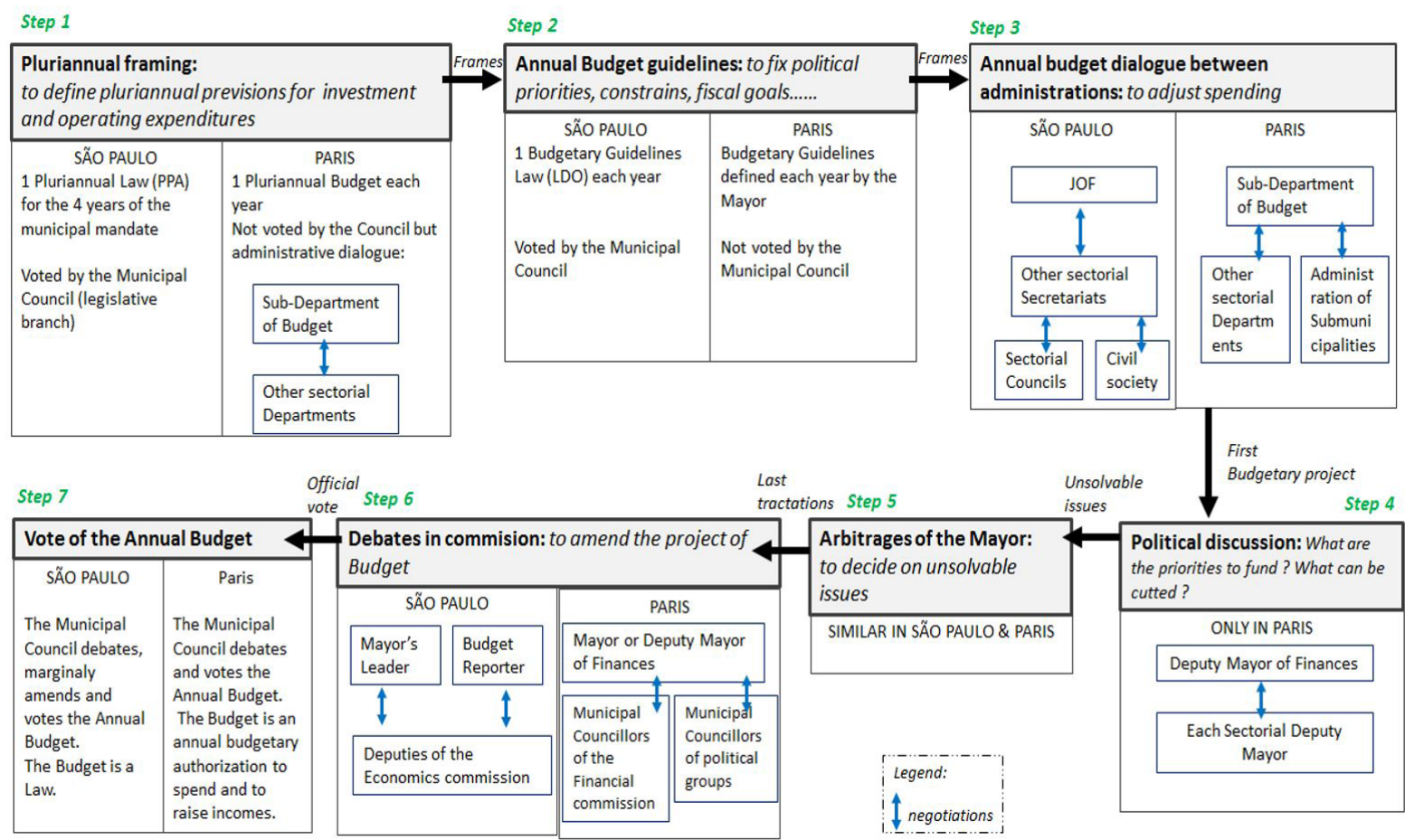

Prepared by the authors, based on constitutional and financial laws, decrees and ordinances of both countries and interviews. 
departments to reach savings or review expected spending. The head of the Budget Department and the heads of Operational Departments then meet to decide how to calculate the amount of spending and which guidelines will be drafted for the next three years.

Step 2 entails determining the annual guidelines to frame the Annual Budget negotiations. In São Paulo, annual guidelines are laid down in the Budgeting Guidelines Law (Lei de Diretrizes Orçamentárias - Annual LDO). The Annual LDO decides how the Annual Budget will be formulated, if any tax increases are to be implemented and defines fiscal goals. This law is formulated from January to April, submitted to the Municipal Council and voted by June. In Paris, the Municipal Council does not vote, and the Mayor's makes the decision. In fact, based on the pluriannual budget, the Budget Department carries out a financial analysis that provides the guidelines for the annual budget, which is presented to the offices of the Mayor and of the Deputy-Mayor in charge of finance to deliberate on the general annual guidelines. These guidelines represent the maximum of annual resources and spending. For instance, deliberations handle the reality of revenues. The Budget Department tends to propose judicious evolution of resources, whereas the offices tend to increase forecasts to obtain more discretion concerning public fund allocation. The Mayor then mandates the Budget Department to produce the final annual budgeting guidelines sent to each Operational Department.

After this framing, a budgetary dialogue begins within the Secretariats/Departments (Step 3). In São Paulo, it initiates at the beginning of the fiscal year, with parameters defined by SUPOM (April or May). In fact, the Annual Budget must respect the guidelines set forth in the PPA and the Annual LDO. Each Department must prepare its individual budget and discuss their needs with both the sectoral councils and with civil society, in contrast to Paris. After the public and sectoral council consultation period, the head of each Department submits a sectoral budget for Board approval. The Board (JOF) tries to understand the specific needs of other Departments, to question their forecasts and their needs, negotiate and make ends meet. However, the actual need for services is only known by other Operational Departments, and not the Budget Department, and may be overestimated or underestimated by the JOF in trading credits. Only the Board and the Mayor know the actual revenues. The relationship between the Board and the target areas is very asymmetric. In Paris, each sectoral Department and each one of the 20 Sub-Municipalities proposes a budget to the Budget Department, and the departments and sub-municipalities are supposed to respect the guidelines. Generally, at the beginning of the negotiation, the departments exceed it with a number of arguments: they cannot find an alternative, it is a mandate from the DeputyMayor in charge of the Operational Department or from the Sub-Mayor in charge of the District, etc. At this first level, administrative experts attempt to reach an agreement and resolve most of the issues. At the second level, Department heads meet to arbitrate persistent issues. If they still disagree, the budgeting conflict is discussed with the General Secretary to return to the guidelines. Monitoring tables indicate the position of each Department (the "Budget" - saver, versus the Operational Department - spender) and their agreement and disagreement during each step.

After this administrative phase, a political phase of the budget process takes place between June and July in Paris (Step 4). This step does not exist in São Paulo where sectoral councils and civil society are more directly associated to the budgetary dialogue. In Paris, the Deputy-Mayor in charge of finance and other sectoral Deputy-Mayors begin their discussion about issues where no consensus was achieved after the administrative phase. Surprises may also occur. For instance, the Deputy-Mayor in charge of sports may ask for new subsidies for an association. Even if this was not expected and discussed in the previous phase, they may argue that the Mayor arbitrated in their favor.

The Mayor then deliberates the final remaining conflicts between the Departments or between the Deputy-Mayors (Step 5). In São Paulo, the Mayor deliberates with the JOF. Discretionary expenditures concentrate the entire dispute. Normally, the Mayor has the final say on how this expenditure will be entered in the budget. As São Paulo has rules to invest in education and healthcare, it is highly likely that the discretionary amount will be used in urban infrastructure, housing, transportation or other expenses. However, it may also be used in culture and 
social welfare, depending on the Mayor and his/her political flag. In Paris, the Mayor may marginally alter what was agreed upon after the political dialogue between Deputy-Mayors. Changes are still framed by the budgeting guidelines, which may concern current less controversial operating expenditures or investment expenditures. In fact, investment expenditures may be funded by credit, which is not the case for operating spending, according to a national rule. Then, accounting entries allow for budgeting program authorizations, which does not imply in executed spending (credits can be commence, but not really spent). Moreover, investments display significant political importance for the budgetary dialogue between the Mayor of Paris and the borough Mayors, even if they only entail a very small portion of the investment expenditure concerning local projects, very functional initiatives (rehabilitation of a street or a park, social initiatives) that directly capture the attention of citizens.

The next step (Step 6) is more crucial in São Paulo than in Paris. In São Paulo, after the Mayor deliberates, the executive branch sends the Annual Budget Project to the Municipal Council by September $30^{\text {th }}$. Then, deputies, members of the Economics Commission of the Municipal Council, debate in this instance and propose amendments. Subsequently, all deputies negotiate amendments with the Mayor's leader in the Council and with the local councils of education, ${ }^{4}$ healthcare, housing, and other social representations. Tractions may be collective during the Public Plenaries of the Municipal Council. They are also bilateral between deputies and the Budget Rapporteur (each year, a rapporteur is elected among Deputies from the Economic Commission of the Council, who has the power to propose the first amendments). Bilateral negotiations can also involve deputies and the Mayor's leader during the Council Plenary on the day they vote on the budget. In Paris, discussion within the Financial Commission allows for few modifications to the Budget project, allowing municipal councilors from non-majoritarian parties to negotiate with the Mayor and the Deputy-Mayor of Finance. In consideration of their approval, they could obtain marginal changes to satisfy a political cause. The main issues and the most difficult negotiations, however, take place earlier. The Mayor and the Mayor's office anticipate late negotiations and maintain some budgeting margins to satisfy their supporters, as a part of the budgeting game.

The construction of the Annual Budget ends by submitting the Budget to the Municipal Council, which votes in December (Step 7). When the Mayor has a comfortable majority in the Council, this stage is symbolic. In São Paulo, over 10,000 amendments to one Budget Law can be proposed and, if the Mayor wants the Annual Budget to be approved, he/she must accept some of them. Subsequently, the executive branch may freeze these expenditures and most of these marginal changes may not be implemented. In Paris, the Budget is submitted in December to the Council of Paris, where Deputy-Mayors and councilors discuss and comment on it. The Council meeting is a forum for political expression, particularly to the opposition, even if the game has already ended.

\section{Where does the municipality spend its budget and why?}

This section presents the expenses of both municipalities, defining what the budget base is in Sáo Paulo and Paris and how relevant this definition is in a very different way in both metropolises. First, two very important concepts to understand the São Paulo case are presented, i.e., incompressible and compressible expenses, and discussed alongside the Paris case. Subsequently, expenses classified into economic categories are analyzed throughout 10 or 12 years, allowing for the identification of evolutions and continuities in expense allocation in both cities.

a) Defining the budgeting basis

The division of resources among public policies becomes an annual budget procedure once the revenue forecast has been defined. Both in São Paulo and in Paris, as well as in OECD countries, the division of expenditures is normally presented by function. This budgeting classification indicates how public money is spent in a) education; b) healthcare; c) transportation; d) social welfare; e) housing; f) culture and others. Usage of international accounting standards can vary marginally, For example, in Brazil, retirement expenses are a function whereas, in France, they are included in other functions and not distinct. 
In São Paulo, defining annual expenditures is not an immaterial procedure that can be planned over only public education, healthcare, transportation demands, among others, vis-à-vis financial availability. Municipal Governments must obey different federal rules, which define great part of the annual budget, regardless of the Mayor's political wing. These rules have been consolidated over the past decades (l) by applying these rules, the São Paulo budget can be categorized into incompressible and compressible expenditures (Rezende, 2015).

Figure 2 presents expenses divided into compressible and incompressible expenses. Incompressible spending cannot be cut without legal changes and are subdivided into two groups: i) mandatory and fixed value and ii) constitutional/legal, which vary according to revenue collection (earmarked revenues). Personnel expenses (active and retired) are allocated in the first group. Earmarking funds for healthcare and education, payment of the debt contract with the central Government, legislative branch expenditures and expenditures associated to payment of courtordered debt payments are placed in the second group. As mentioned in section 4.2.1, health and education expenditures represent an important amount of São Paulo's budget, as these areas have earmarked revenues 5 . Predetermined incompressible expenditures also include expenditures linked to Growth Acceleration Program credit operations, as this spending is dependent on federal income transfers and can only be used for the specific objective of the contract.

Incompressible expenditures achieve an amount that can vary slightly according to the revenue mix, but generally comprises about $80 \%$ of net current revenues. Figure 2 illustrates the expenses in two different administrations, the Haddad, 2014 administration, and Doria/Covas, 2018 administrations $^{6,7}$, considering their first Annual Budget Law. Between R $\$ 64.6$ billion and $\mathrm{R} \$ 59.5$ billion were committed to predetermined expenditures in both periods (approximately 80\%).

"Compressible expenditures" contains expenses associated to the maintenance of the government, urban services, and investment machinery (discretionary ones). No legal or constitutional support ensures their permanence in the budget. They can, therefore, be renegotiated, restricted and/or cut. In São Paulo, this part accounted for approximately $\mathrm{R} \$ 11$ to 13 billion (20\% of the budget) in 2014 and 2018 . However, half of this amount comprises urban services (public transportation, cleaning, and public lighting), which are basic and cannot be easily cut. The remaining

Figure 2

\section{Sáo Paulo budgets for 2014, of R\$ 64.6 billion, and 2018, of R\$ 59.5 billion}

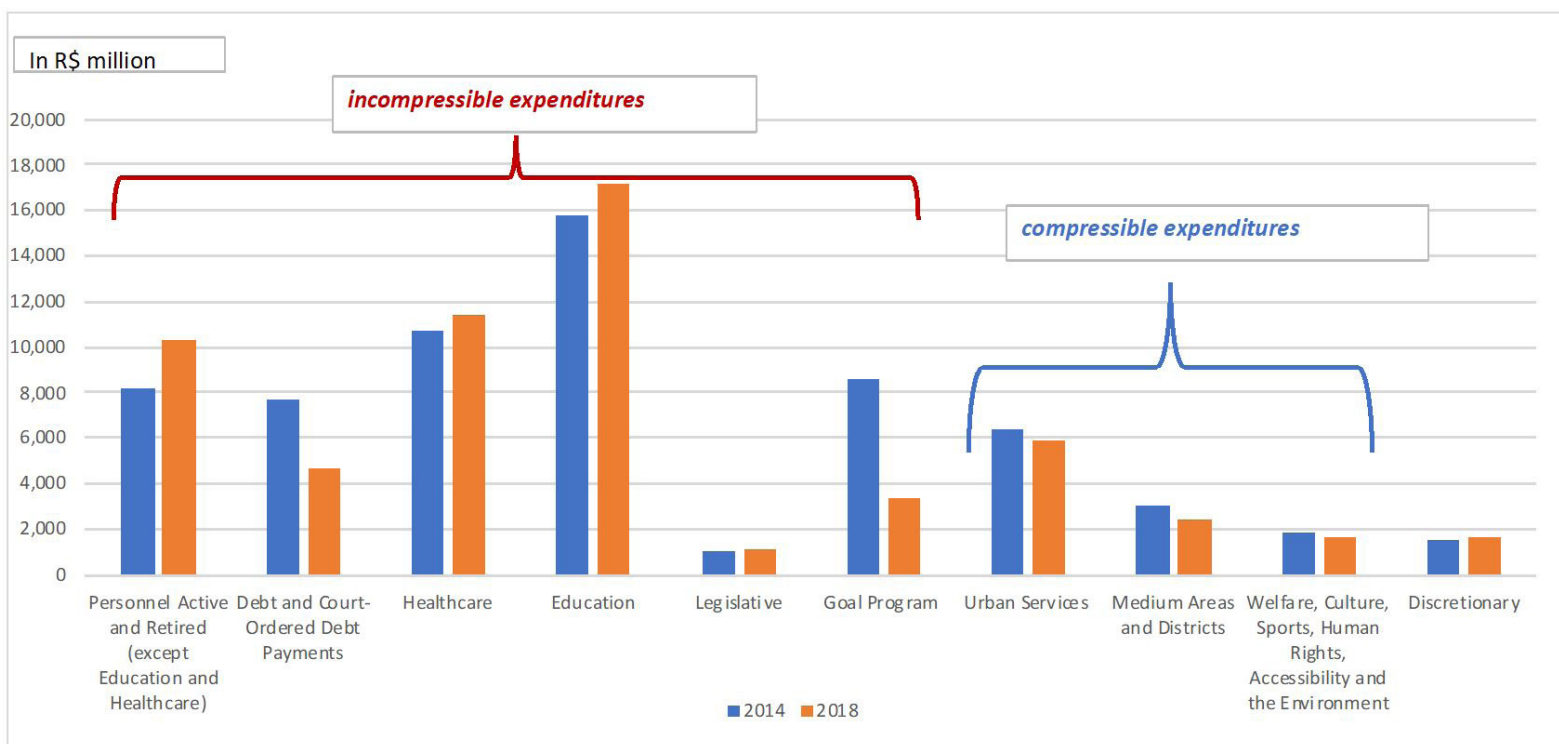

Prepared by the authors, based on the São Paulo Municipality Budget, 2014 and 2018 (in R\$ millions - 2018/IPCA). 
$\$ 5$ billion is dedicated to a myriad of compressible expenditures, such as welfare, human rights, culture, sports and leisure planning, as well as maintenance of moderate areas such as finance, management, legal matters, and city cleaning, which is mostly carried out by the 32 districts.

As a result, only $\mathrm{R} \$ 1.5$ billion of the "discretionary expense" is susceptible to be negotiated among players. Within an administration structured by over 60 agencies (Secretariats, Sub-Municipalities and others), the competition for this increment is quite fierce, even for agencies that already have pre-defined resources. The continuation of activities throughout the years always leads to pressure for more resources. If the demand for services is greater than the supply and if a historical deficit of services exists, such as in education and municipal healthcare, the quest for an increment beyond the already earmarked funds is unavoidable.

Although a budget reduction is noted between 2014 and 2018 (due to the economic crisis in Brazil), Figure 2 indicates the incremental growth of three core areas: personnel, education and healthcare. As explained previously, these areas are protected by special rules. When also taking into account path dependence (Pierson, 2000), the result is that spending in these sectors grows with a certain inertia. This increase can be led by an increment from revenues and/or from reducing the revenues dedicated to other areas. Thus, as revenues were not increasing between 2014 and 2018, the growth of these expenses was made possible by the reduction of debt service (renegotiated by the Haddad Administration) and the lower volume of expenses considered in the goal program (comprising expected federal funding (PAC) during the Haddad Administration, it was and funded with the expectation of Public-Private Partnerships, in a much smaller volume, during the Doria/Covas Administration).

Thus, these compared columns indicate the spending inertia of both Administrations from different parties, but also important changes in allocation decisions regarding potential investments (goal program) and their funding sources, as result of the political discretionary power of Mayors.

In Paris, the budget allocation model is quite different from São Paulo, as there are no legal rules for earmarking revenues or constitutional protection for certain types of expenses. One of the most significant difference concerns health and education: Paris is not obliged to spend a fixed percentage of local taxes to fund health and education. Thus, city expenses are allocated per public activity sector (Figure 3), according to the negotiation process presented in section 4.2. The presentation of the budget per function is very new and the comparison between the mandates of Mayor Delanoë (2008-2014) and of Mayor Hidalgo (2014-2020) is complicated. ${ }^{8,9}$ Unlike São Paulo, Paris does not have "uncompressed expenses", as defined previously. Even so, one can identify a budget base in Paris comprising personnel expenditures and part of social and equalization expenses (the latter two are earmarked). These expenditures are mainly categorized into two functions, general services and welfare and solidarity, two of the most important (Figure 3). "General services" includes general administration expenses (such as energy, vehicles for civil servants, subsidies for the districts and municipal asset maintenance, among others) and "welfare and solidarity" includes the funding of unemployment insurance, autonomy pension for low-income elderly people, etc. The third most important function consists of urban services, urbanism, and the environment (waste management, water supply) where great part of the Paris investment is allocated. This division remained quite stable during the 2014-2018 period (Figure 3).

Part of the variations observed from 2014 to 2018 are due to the evolution of function perimeters. However, one can note that the two most important functions in volume increased more than others, namely general services and welfare and solidarity. This is the result of the structure of these functions being mainly based on personnel expenses - part of the budgeting base. As presented in the next subsection, personnel spending is the most important economic category in Paris, and has been increasing incrementally for several years.

On the other hand, it is impossible to distinguish a discretionary part of the budget allocated by the Mayor thanks to these macro-categories. It would be necessary to focus on a sectoral public policy and analyze several years of it budget (amounts and types of spending or funding). 
Figure 3

City of Paris expenses by function from 2014 to 2018

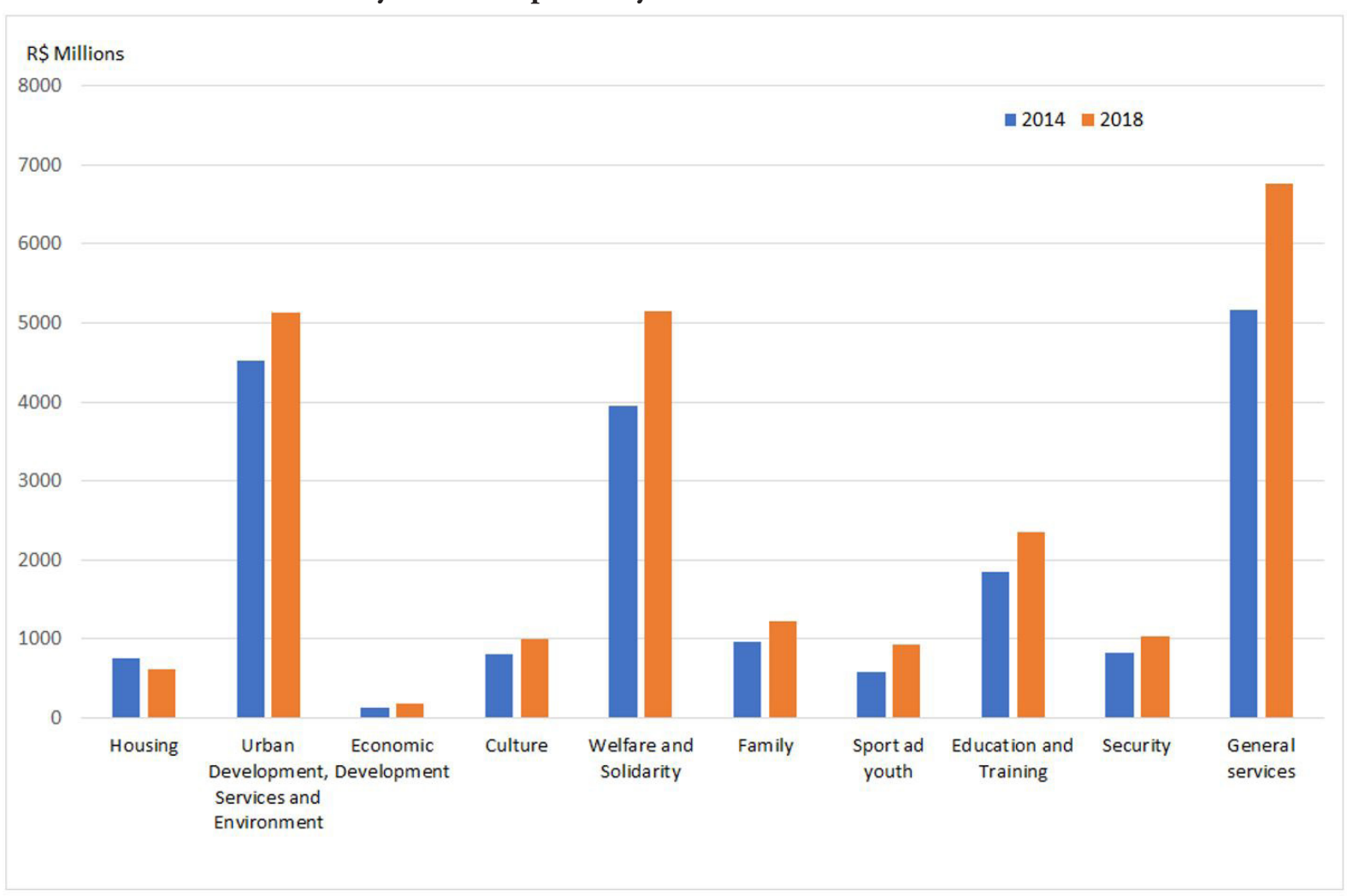

Prepared by the authors, based on Paris' budgets from 2014 to 2018 (in R \$ Million).

b) Evolution of expenditures per economic categories

The analysis of budget expenditures per economic classes makes it possible to understand how the budget is categorized among past activities and choices (personnel, debt and already contracted services), explained by a path dependency process analyzed by Pierson (2000) and new ones (essentially, investments). Normally, part of the current investments will require new personnel expenditures to work in hospitals, schools, cultural spaces, or outsourcing contracts to operate public services or new maintenance contracts for roads and others. Therefore, there should be some balance between inherited and new activities concerning income allocation. As a significant part of the budgeting expenditure (the base) is defined by past decisions and increases incrementally throughout the years, to create new annual expenditures (investments), it is necessary to obtain enough increment to pay for both inherited and new activities. One exception to this trend is noted: in periods of severe economic scarcity (Schick, 1976), some contracts may be broken, and budget punctuations may happen (Jones et al. 1998), in order to reduce past expenditures and open room for new ones or to imbalance the budgets.

Comparing data for Sáo Paulo and Paris, two different economic scenarios that share something in common: personal expenditures are growing incrementally. First, in the case of São Paulo (Figure 4), some expenditure items increased more rapidly from 2008 to 2018, such as expenses with personnel and outsourced services, implemented by private companies or social organizations. These categories rise as a percentage even higher than the increases in revenue, which means that the space for other categories, such as investments, became reduced. Therefore, the increment was not enough to maintain past and increasing new expenditures, as result of revenue stagnation, as discussed in section 4.4 . 
Figure 4

Municipality of Sáo Paulo: Evolution of expenditures per Economic Category - 2003/2018

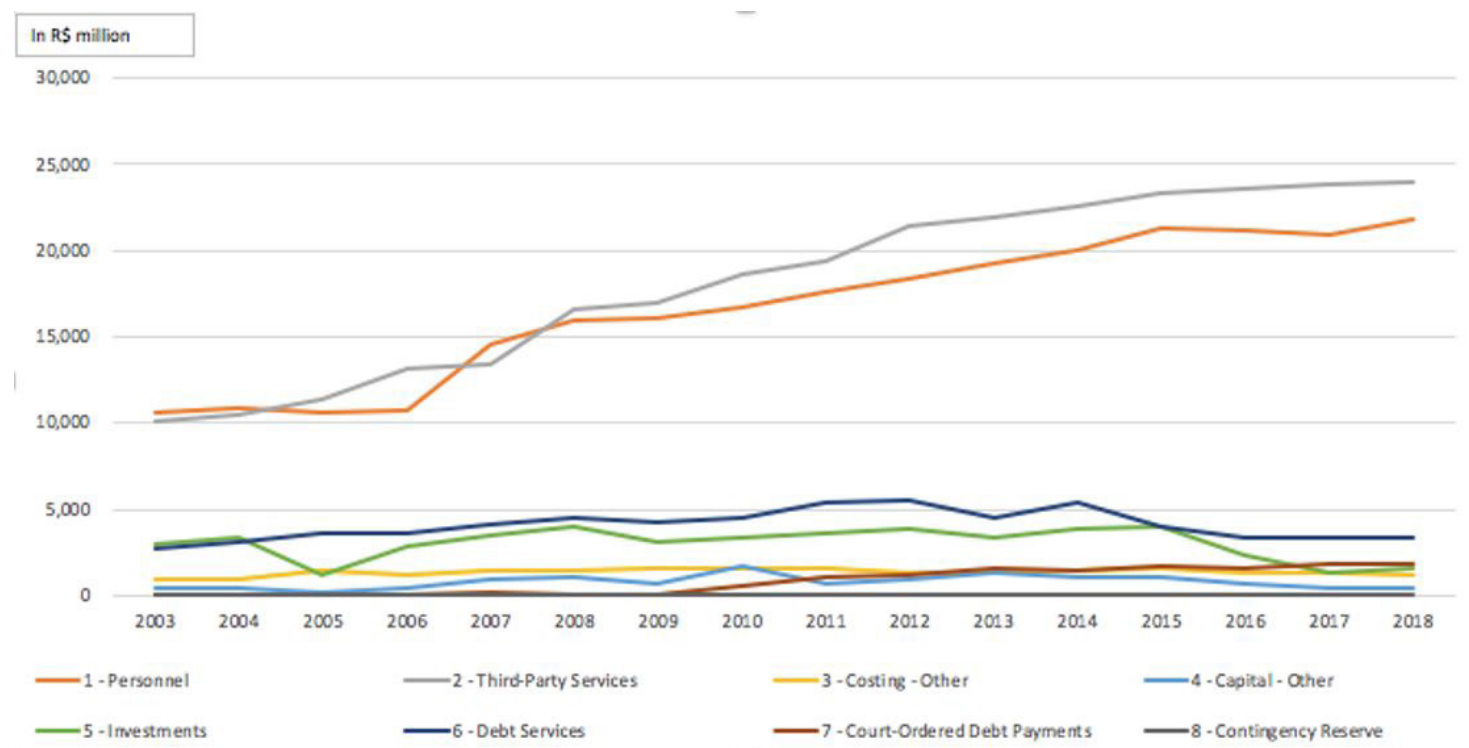

Prepared by the authors, based on the São Paulo Municipality budget for 2003/2018 (in R \$ Million - 2018/IPCA).

In Paris (Figure 5), personnel expenses are also the most important concerning the division of economic categories and have increased incrementally over the last two political mandates (2008-2014 and 20142018). The regular increase of personnel expenses is due to several factors, including the recurring monetary adjustment of municipal employee wages, decided by the Central Government for all government employees, the Elementary School reform, voted by the Parliament, which implied in hiring employees for extracurricular activities, and the ageing of municipal employees, that implies in an automatic increase of their wages, among others. Personnel wages account for approximately $25 \%$ of the annual budget, where $\mathrm{R} \$ 6.2$ billion are spent to fund approximately 53,000 employees (€2.343 Million).

In contrast to São Paulo, an important volume of investments was noted in Paris. Investment variations are documented by observers. Usually, local public investment increases progressively during the mandate, low during the first two years after a municipal election, increasing in the following years (see Figure 5). The sharp rise in tax income enables this progression (see section 4.4.). In addition, social expenditures increase due to an increase in the number of people asking for social aid (especially the social minimum wage, which is a mandatory spending for Paris given its legal responsibilities).

Finally, equalization of mandatory expenditures established by national law, comes up during the period, a financial mechanism created by the Central State to redistribute financial resources among local authorities (municipalities, inter-municipalities, departments, regions). This mechanism, based on different resource and charge indicators, consists of drawing money from the "richest local authorities" to allocate it to the "poorest". It offsets a decrease in subsidies allocated to local authorities by the Central State. As the municipality of Paris is considered rich, it increasingly contributes to national solidarity. Other expenditures increase regularly over the years.

These different expenditure increases, both past and new, illustrate important differences between the Paris and São Paulo budgets. Firstly, Paris has been dealing with increasing revenues for the past years, especially in the investigated period. Therefore, it is possible to accommodate incremental growth of the basis and new investments. São Paulo expenses on the other hand, are subject to different rules (earmarking and other constitutional protection) that comprise a significant portion of the basis of mandatory expenditures. These rules reinforce the 
Figure 5

City of Paris: Evolution of the main expenditures per economic categories (2006/2017).

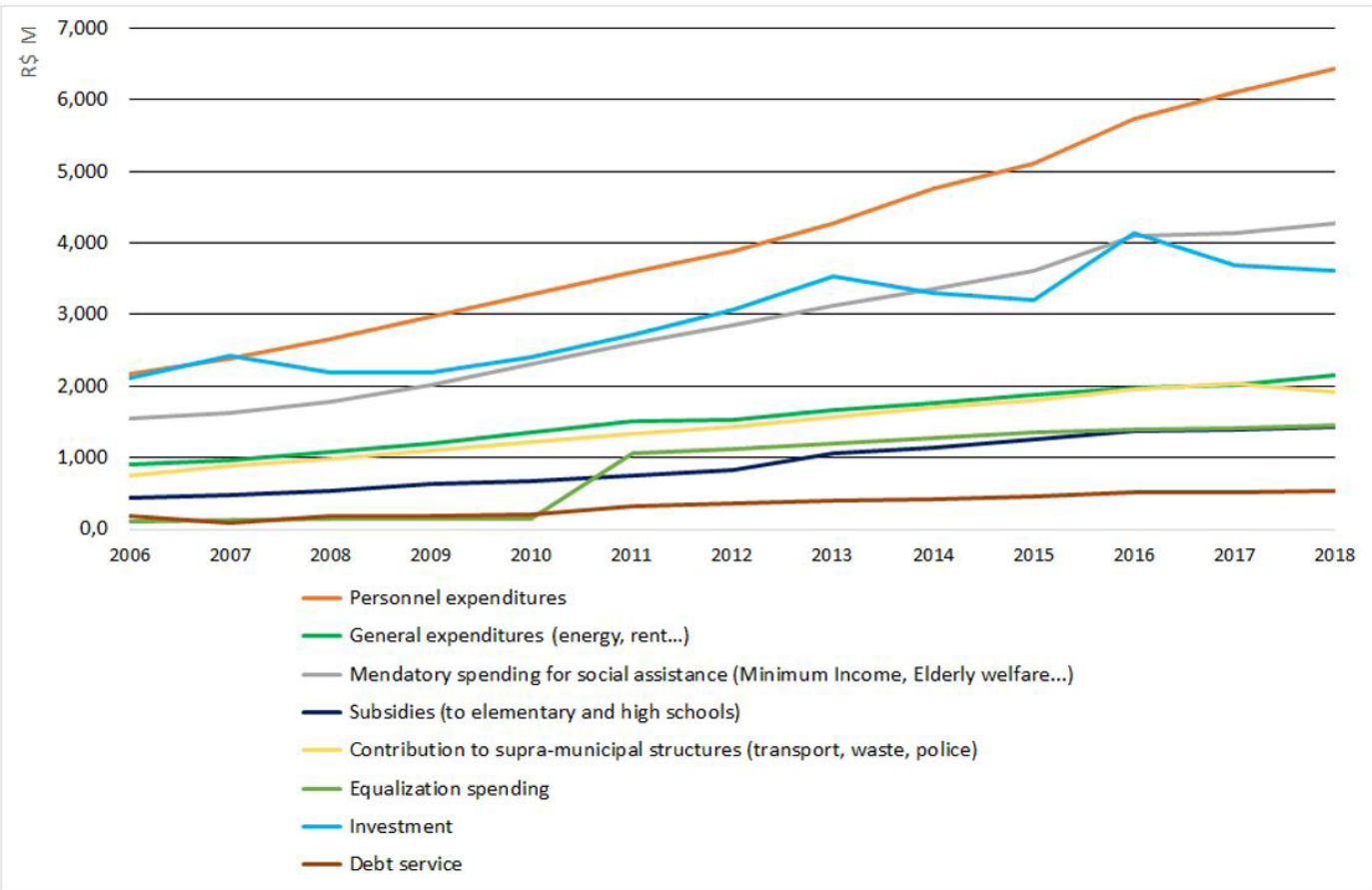

Prepared by the authors, based on Paris City Budgets for the period of 2006-2018 (in R\$ Million).

budgetary incrementalism of the basis, making it almost mandatory to cut new investments when revenues decrease.

\section{Limited and uncertain resources}

The amount of revenue determines the budgeting and political capacity of a municipality to implement public policies. Therefore, the origin of the revenues (subsidies from the Federal or State level, shared taxes, local taxes, commercial revenue from public services) is important as it influences the capacity of the municipality to adjust its revenues to its spending.

In São Paulo, public funding depends on both local revenues and state and federal grants, all defined by Constitutional Law. As São Paulo is a very powerful economic metropolis, its local revenues are more relevant than the grants, in contrast to $90 \%$ of other Brazilian municipalities. In Paris, as in São Paulo, direct local taxes account for $45 \%$ of current municipal revenues. If we take into account indirect taxes and charges in addition to local direct taxes to,
Table 7

Comparison of the source of municipal revenues in São Paulo and Paris

\begin{tabular}{lcc}
\hline $\begin{array}{c}\text { Level of } \\
\text { funding }\end{array}$ & Săo Paulo & Paris \\
\hline Federal level & $R \$ 0.7$ billion $-6.7 \%$ & - \\
\hline State level & $R \$ 0.5$ billion $-4 \%$ & $R \$ 2$ billion $-11.6 \%$ \\
\hline Municipal level & $R \$ 8$ billion $-89.3 \%$ & $R \$ 20$ billion $-88.4 \%$ \\
\hline
\end{tabular}

Prepared by the authors, based on the Annual Budget Balance for São Paulo (2018) and for Paris (2018).

these account for $70 \%$. Considering all the revenues raised by the municipal level, they have increased to $88.4 \%$ of the current revenue (Table 7 ).

To a certain extent, the municipality of Paris can adjust part of its local taxes. For instance, the Municipal Council can adopt a new property tax rate, allowing the city to not be too dependent on Central State subsidies. In São Paulo, as in Paris, most of the revenues come from local taxes, such as service tax and property tax, and part of them may 
be adjusted by raising tax rates. As discussed above, despite this tax capacity, almost $80 \%$ of these revenues are earmarked by the Federal Constitution, regardless of the Mayor's will, which generates a budgeting constraint. The margins to define discretionary allocation are reduced to a small percentage or will depend on capital revenues, such as urban operations. This budgeting constraint by earmarked revenues is not applied to the city of Paris, a significant difference compared to the Brazilian case.

In São Paulo, Figure 6 indicates the major municipal revenue categories, accounting for over $80 \%$ of the total collection. Increasing revenues from 2008 to 2013 are observed, followed by an oscillation in the municipal services tax "Imposto sobre Serviços - ISS", the most important in São Paulo, as well as an important and continual reduction in the "Imposto sobre Circulação de Mercadorias e Serviços - ICMS” (a state value-added tax on services and goods circulation), that used to be the second most important tax. Thanks to a new law that reviewed the property tax from 2014, this tax has increased in order to offset the consumption tax decrease. The final result of these tax movements is revenue stagnation in the past three years, decreasing investments and discretionary expenditures, as discussed in previous sections.

In Paris, in 2018, tax revenue accounted for approximately $60 \%$ of the current consumption income over the years, as shown in Figure 7. Property tax revenues are the most important part of tax revenue. The tax on real estate transactions accounts for approximately $17 \%$ of current consumption income and $30 \%$ of tax revenue. Due to the real estate market dynamic in Paris, this income increases regularly. However, when the cycle ends, which is not predictable, an important part of city revenue is impacted. This resource uncertainty is part of the variable that can be used by politicians to increase the primitive budget and spend more. Subsidies from the Central State to fund decentralized responsibilities (earmarked funds) are decreasing, where Paris has to support these public policies with increasingly less financial support from the State (for instance, social aid is increasingly funded by the city, whereas this public policy is decided by the Central State). Global subsidies to fund current spending represent a very small part of Paris municipality revenues and decrease slowly each year. Operating revenue includes

\section{Figure 6}

\section{City of Sáo Paulo - Evolution of main revenues (2008/2018)}

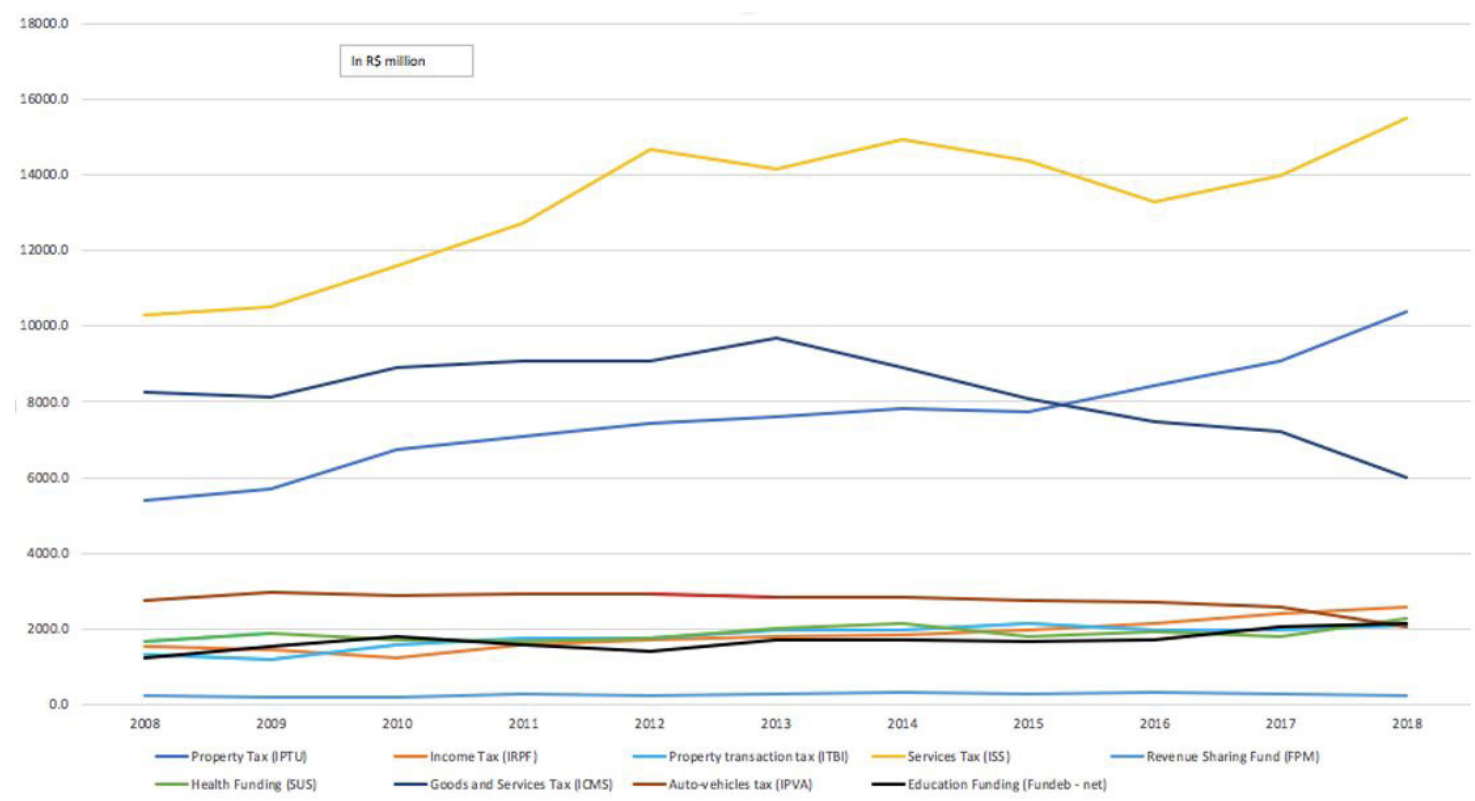

Prepared by the authors, based on São Paulo Municipality Budgets for the period of 2008/2018 (in R\$ Millions - 2018/IPCA). 
Figure 7

City of Paris - Evolution of main revenues (2006/2018)

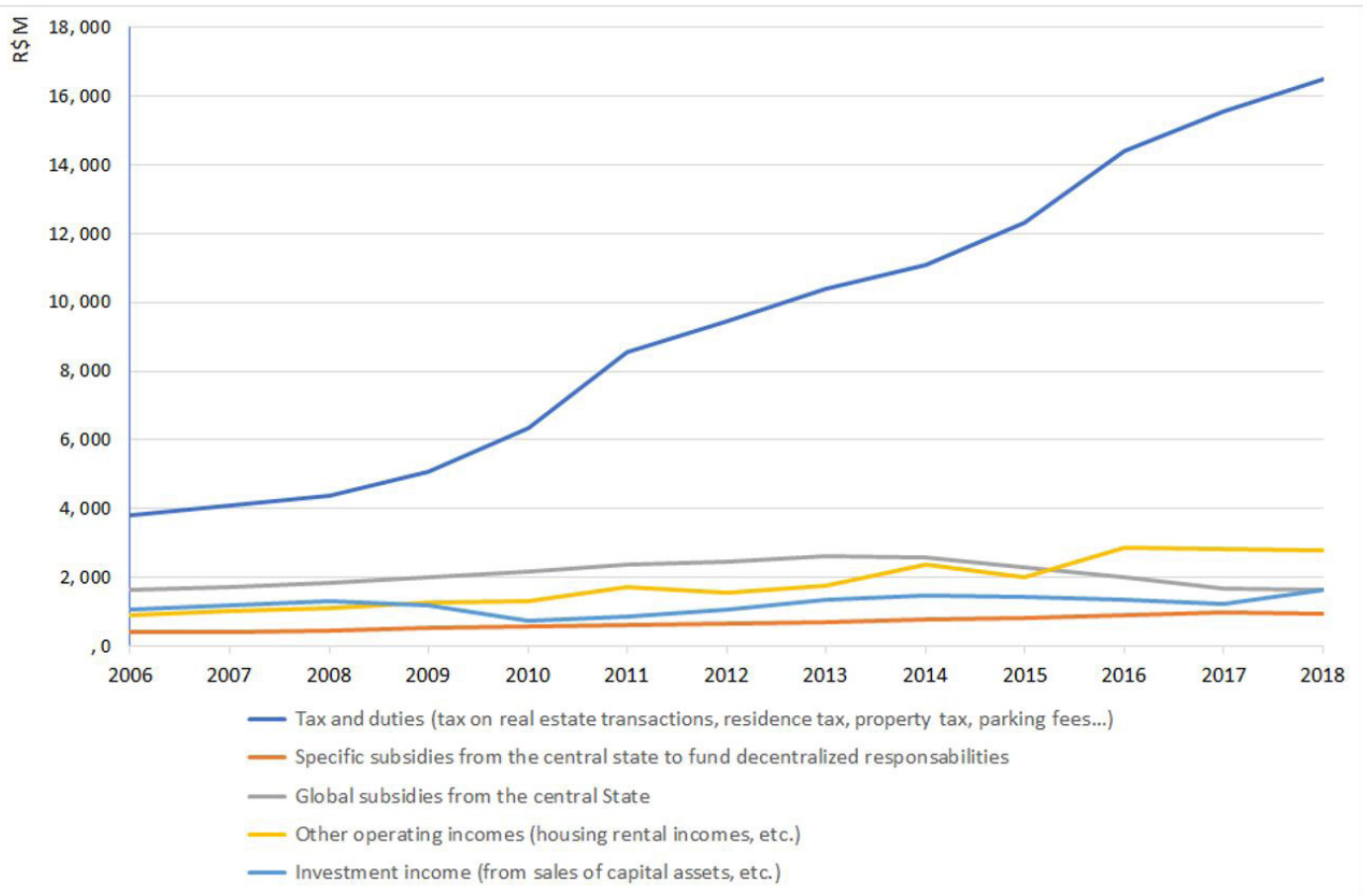

Prepared by the authors, based on Paris City Budgets for the period of 2006-2018 (in R\$ Millions).

revenue from real estate sales, tariff revenues (for example, tariffs paid to benefit from public swimming pools, sports centers and municipal kindergartens, among others) and public service concession holders' revenues. These funds are increasing in order to offset the reduction of State subsidies.

\section{Conclusion}

The aim of this paper was to compare two different metropolises, São Paulo and Paris, to investigate potential similarities in their budgetary governance and in budget structure, despite political, administrative and economic differences. From the comparison of these very different cases, we present some common points and differences concerning the budget structure and evolution and the budget process of both cities.

The present comparison demonstrates differences within similarities as both cases, with very different macro institutions (federal versus unitary States), similar meso-institutions (organization of municipal institutions, municipal public policies, budget planning), but different rules, generate interesting differences in the process and some divergence in results.

Comparing Budget evolutions, thanks to a sharp increase in taxes and charges, Paris can continue to invest and fund public policies. The increase in revenue and the absence of the earmarked revenue rules allow for more discretion in revenue allocation. On the other hand, in São Paulo, revenue stagnation, in addition to rule rigidity and hard budget constraints make little room for discretion and, particularly, for investment. In both countries, certain expense items grow incrementally. The budgeting basis, comprised of personnel expenditures, essential contracts, debt service, (and, in Paris, equalization spending and part of social spending) is somehow protected and tends to increase over the years, even if there is no special rule for such. Indeed, public administration is responsible for a package of competences and engaged in a path dependence process that results in past decisions influencing the present (Lindblom, 
2009; Pierson, 2000). In São Paulo, the basis includes all healthcare and educational expenditures, as they comprise earmarked spending. In Paris, even without earmarked spending, part of the expenditure tends to be protected and increase (personnel, social and equalization expenses).

Both metropolises are submitted to austere fiscal controls from different levels of federal, national, and international (European Community, IMF) governance. Therefore, the municipal budgeting bureaucracy usually tends to control deficit limits, while they have to deal with incremental expenditure increases. As a result, discretionary expenditures (unprotected by laws or not essential) will be reduced in cases of scarcity or due to external pressure. As discretionary expenditures are essentially linked to new investment programs, these decisions are highly political and, most of the time, very mediatic (Baumgartner and Jones, 1993). Thus, the evolution of the total budget expenditures depends on the combination of different kinds of expenditures, such as the basis, normally affected by incrementalism and inertia, and the discretionary, linked to political decisions. Punctualism explains a very small part of the budget, i.e., the discretionary part. When changes are very massive as in the between Haddad (2014) and Doria/ Covas (2018) Governments in some sectors in São Paulo (education, healthcare), punctualism can be observed by economic spending variations. However, when punctuations are less impressive, such as in Paris, we should focus on a sectoral public policy and analyze its budget at a finer scale to show changes.

In both cities, the budget process follows the same seven-stop pattern. However, this process is much more institutionalized and austere, due to the existence of municipal budgeting laws, a formal budgeting board to drive the budget, and a formal vote of these laws by the Council, among others, in São Paulo than in Paris, which has a pluri-annual budget and guidelines not adopted by the City council as well as no formal board, among others.

São Paulo's mayor, despite governing the wealthiest city in Brazil, has to deal with a small discretionary amount of the annual budget and solve a complex distributive conflict among several groups of interests. Paris' mayor, despite governing a capital in a unitary country, seems to have more autonomy than the mayor of São Paulo, in a federal one.

The complexity of the budgeting game (important number of formal - and informal - rules, the complexity of the subjects involving fiscal laws, etc.) contributes to limit negotiations to insiders who know how the budgeting game is played. This complexity of budgeting rules requires a hierarchical bureaucracy; specialists are required to monitor the budget in detail, and generalists (heads of the budgeting bureaucracy) must supervise each subpart of the budget. This division of tasks also maintains complexity. Moreover, the complexity of the budget process strengthens the incremental growth of the budgeting basis as it is complex to understand existing rules to change them and as the negotiation of "the increment" is easier than the renewal of the entire budget. In this way, inertia becomes a natural pattern of evolution inside the budget process, especially to the basis.

Another step in this research would be to analyze budgetary incrementalism or punctuation in specific projects or public policies, which required more separation and a longer data series. This supplementary enquiry would enable a deeper understanding of budgeting negotiations between individual and collective players (especially political groups and citizen associations), their respective importance in the budgeting game and their distinct motivations. It would help to demonstrate how they contribute with the "board's" political decision-making concerning expenses and revenues, how far the discretionary power of the Mayor goes in this process and how far formal and unformal rules can constrain capacity arbitrating.

\section{Acknowledgments}

This study was developed under the Project "Governance of Large Metropolises", coordinated by Patrick Le Galès (Sciences Po) and Eduardo Marques (USP/CEM), sponsored by grant-2019/09161-3 from the São Paulo Research Foundation (FAPESP), Brazil and the USP-Sorbonne Cité agreement. The authors would like to thank both professors for all suggestions for the improvement of this paper and the RBCS reviewers. 


\section{Notas}

1 "One of the constants of budgeting is the division of roles into spenders and savers, a result of the universal scarcity of resources. Claims and demands always outweigh the resources to satisfy them. Hence there are always people who want more than they have and those who show them they can't have as much as they would like. Officials in charge of carrying out the Government's functions are oriented toward needs. They are always confronted with things that are not done but should be done. They fulfill their task best by advocating these needs. For this reason, the Government's purse needs guardians who would ensure spending does not go beyond available resources and that all spending advocates get a share of what is available" (Wildavsky, 1975, p. 187).

2 National Observatory of Local Finance, Report, 2019.

3 See Pinto (2018) and Mendes and Funcia (2016).

4 The Mayor's leader is a deputy elected after the municipal election, from the same political party as the Mayor or from a political coalition.

5 In São Paulo the earmarked revenues for education is even higher than set in the Federal Constitution. The local law defined that $31 \%$ of local taxes shall finance education (PERES, 2018).

6 Haddad was elected the Mayor of São Paulo in 2012, as a Workers' Party (PT) candidate, and held office from 2013 to 2016. He was the former Minister of Education during the Lula and Dilma administrations, is a lawyer and holds a PhD in Philosophy.

7 Doria is a journalist and a well-known marketing entrepreneur that initiated in politics in the Social Democrats Party (PSDB), alongside the former renowned governor Mario Covas. Doria was elected mayor in 2016, in a local dispute with Fernando Haddad. However, he only held office for a year and a half, leaving the São Paulo Mayor position for a new dispute, the state government. As he won in 2018, Bruno Covas (the grandson of Mario Covas) vice-mayor, also from PSDB, took on as the new mayor for the municipality.

8 Bertrand Delanoë is a French socialist politician. First Senator and municipal councillor, he was elected Mayor of Paris in 2001 and reelected in 2008. He left the Municipality in 2014 before the end of his second mandate and was replaced by Anne Hidalgo.

9 Member of the French Socialist Party, Anne Hidalgo was municipal councillor from 2001 to 2014. She became the trusted vice-deputy of Delanoë in charge of urbanism. She was elected Mayor of Paris in 2014 and reelected in 2020 .

\section{REFERENCES}

ALLÉ, Camille. (2017), Les politiques des finances publiques locales. PhD Thesis. Sciences Po - Institut d'études politiques de Paris, Paris.

ARRETCHE, Marta. (2012), Democracia, federalismo e centralização no Brasil. Rio de Janeiro, FGV/ Editora Fiocruz.

BAUMGARTNER, Frank R. \& JONES, Bryan D. (1993), Agendas and Instability in American Politics. Chicago, The University Press of Chicago.

BAUMGARTNER, Frank R.; FOUCAULT, Martial; FRANCOIS, Abel. (2011), "Lincrémentalisme et les ponctuations budgétaires en France", in P. Bezès \& A. Siné (org.), Gouverner (par) les finances publiques, Paris, Presses de Sciences Po. BERRY, William D. (1990), "The Confusing Case of Budgetary Incrementalism: Too Many Meanings for a Single Concept", The Journal of Politics, 52, 1:167-96. DOI: $10.2307 / 2131424$.

BEZES, P., \& SINÉ, A. (2011). "Introduction", in P. Bezes \& A. Siné (org.) Gouverner (par) les finances publiques, Paris, Presse de Sciences Po.

CORE, Fabiano. (2007), "Reforma Gerencial dos Processos de Planejamento e Orçamento", in J. Giacomoni, \& J.L. Pagnussat (org.), Planejamento e Orçamento Governamental, Brasília, ENAP.

DOUILLET, Anne-Cécile \& LEFEBVRE, Rémi. (2017), Sociologie politique du pouvoir local. Paris, Armand Colin.

FUCHS, Ester. (1992), Mayors and Money: Fiscal Policy in New York and Chicago. Chicago, The University of Chicago Press.

HAYWARD, Jack. (1976), "Institutional inertia and political impetus in France and Britain". European Journal of Political Research, 4, 4: 341-59. DOI: 10.1111/j.1475-6765.1976.tb00539.x.

JONES, Bryan D. \& BAUMGARTNER, Frank R. (2005), "A model of choice for public policy". Journal of Public Administration Research and Theory, 15, 3: 325-51. DOI: 10.1093/jopart/ mui018.

JONES, Bryan D.; BAUMGARTNER, Frank R.; TRUE, James L. (1998), "Policy punctuations: US budget authority, 1947-1995". The Journal of Politics, 60, 1: 1-33. DOI: 10.2307/2647999. 
LASCOUMES, Pierre \& LE GALÈS, Patrick. (2012), "A ação pública abordada pelos seus instrumentos". Revista Pós Ciências Sociais, 9, 18: 9-44.

Le GALÈS, Patrick. (2006), "Les deux moteurs de la décentralisation. Concurrences politiques et restructuration de l'Etat jacobin", in P.D. Culpepper (org.), La France en mutation. 19802005, Paris, Presses de Sciences Po.

Le LIDEC, Patrick. (2011), "La décentralisation, la structure du financement et les jeux de transfert de l'impopularité en France", in P. Bezes \& A. Siné (org.), Gouverner (par) les finances publiques, Paris, Presses de Sciences Po.

LINDBLOM, Charles Edward. (2009), "Muddling through 2: a ubiqüidade da decisão incremental”, in F.G. Heidemman \& J.F. Salm (org.), Politicas públicas e desenvolvimento: bases epistemológicas e modelos de análise, Brasília, Editora UnB.

MARQUES, Eduardo \& HOYLER, Telma. (2018), "Política e coalizões de governo", in E. Marques (org.), As politicas do urbano em São Paulo. São Paulo, Editora UNESP.

MARQUES, Eduardo. (2013), “Government, political actors and governance in urban policies in Brazil and São Paulo: concepts for a future research agenda", Brazilian Political Science Review, 7, 3: 8-35. DOI: 10.1590/s1981-38212013000300001.

MENDES, Áquilas \& FUNCIA, Francisco Rózsa. (2016), "O SUS e seu financiamento", in R.M. Marques; S.F Piola; A.C. Roa (org.), Sistemas de Saúde no Brasil: organização e financiamento, Rio de Janeiro, ABrES; Brasília, Ministério da Saúde, Departamento de Economia da Saúde, Investimentos e Desenvolvimento; Brasília, OPAS/OMS no Brasil.

MILLER, Gary J. (1992), Managerial dilemmas: the political economy of hierarchy. Canada, Cambridge University Press.

PERES, Ursula Dias. (2007), "Custos de transação e estrutura de governança no setor público”. Revista Brasileira de Gestão de Negócios-RBGN, 9, 24: 15-30.

PERES, Ursula Dias. (2018), "Análise da Governança do Orçamento Público”, in E.C.L. Marques (org.), As políticas do urbano em Sáo Paulo. 1st edition, São Paulo, Unesp.

PIERSON, Paul. (2000), "Increasing returns, Path Dependence, and the study of Politics". The American Political Science Review, 94, 2: 251-267.

PINTO, José Marcelino de Rezende. (2018), “O financiamento da educação na Constituição Federal de 1988: 30 anos de mobilização social". Educação \& Sociedade, 39, 145: 846-869. DOI: 10.1590/es0101-73302018203235.

REZENDE, Fernando. (2015), A Politica e a Economia da Despesa Pública. Escolhas Orçamentárias, ajuste fiscal e gestão pública: elementos para o debate da reforma do processo orçamentário. Rio de Janeiro, Editora FGV.

SCHICK, Allen. (1976), "O PPB e o orçamento incremental”. Revista de Administração Pública, 10, 2: 65-84. DOI: 10.3917/pouv.110.0005.

SCHICK, Allen. (2009), Evolutions in budgetary practice: Allen Schick and the OECD Senior Budget Officials. Paris, OECD.

SCHNEIDER, Aaron. (2005), "Conflito político e instituiçóes orçamentárias: aprofundando a democracia no Brasil". Revista de Sociologia e Política, 24: 87-103. DOI: 10.1590/s010444782005000100007.

SEAWRIGHT, Jason \& GERRING, Jones. (2008), "Case Selection Techniques in Case Study Research: A Menu of Qualitative and Quantitative Options”. Political Research Quarterly, 61, 2: 294-308. DOI: 10.1177/1065912907313077.

WILDAVSKY, Aaron B. (1964), The Politics of the Budgetary Process. Boston, Little, Brown and Company.

WILDAVSKY, Aaron B. (1969), Budgeting: A Comparative Theory of the Budgeting Process. Boston, Little, Brown and Company.

WILDAVSKY, Aaron B. (1975). A comparative theory of budgetary processes. Boston, Little, Brown and Company.

WILDAVSKY, Aaron B. \& CAIDEN, Naomi. (2004), The new politics of the budgetary process. New York, Pearson/Longman. 


\section{COMPARING BUDGETARY STRUCTURES AND PROCESSES: THE CASES OF PARIS AND SÃO PAULO}

\author{
Ursula Dias Peres, Camille Allé
}

Keywords: Public finance; budget process; comparative analysis; Paris; São Paulo.

This article compares the structure of the city budget of São Paulo and Paris and their processes between 2008 and 2018, aiding in the understanding of budgetary decisions and contributing to the literature on public budgets, more focused on national and federal levels. As the budget process is very technical and standardized, one should observe several similarities between both cases This article demonstrates how similar the budget structures and processes of these two metropolises are. It indicates, for example, that both present incrementalisms in their budget base, as expected according to theory. However, the study also indicates differences within similarities as both cases, with very different macro institutions (federal versus unitary States), similar meso-institutions (organization of municipal institutions, municipal public policies), but certain different rules, generate important differences in their processes and some divergence in their results.

\section{COMPARANDO ESTRUTURAS E PROCESSOS ORÇAMENTÁRIOS: OS CASOS DE PARIS E SÃO PAULO}

\author{
Ursula Dias Peres, Camille Allé
}

Palavras-chave: Finanças Públicas; processo orçamentário; análise comparativa; Paris; São Paulo.

Este artigo compara a estrutura orçamentária da cidade de São Paulo e Paris entre 2008 e 2018 e seus processos, colaborando para a compreensão das decisōes orçamentárias e para literatura sobre orçamento público, que é mais focada nos níveis nacional e federal. Como o processo orçamentário é muito técnico e padronizado, é possível observar muitas semelhanças entre esses dois casos diferentes. Este artigo mostra então, quão similares são as estruturas e processos orçamentários dessas duas metrópoles. Indica, por exemplo, que ambas apresentam um crescimento incremental da base orçamentária, conforme esperado, de acordo com a teoria. No entanto, o artigo também mostra diferenças dentre as similaridades, visto que os dois casos, com instituiçóes macro muito distintas (estado federativo versus unitário), meso-instituiçóes similares (organização das instituições municipais, políticas públicas locais e outras), mas com algumas regras distintas, geram diferenças importantes no processo orçamentário e algumas divergências de resultados.

\section{PROCESSUS ET STRUCTURES BUDGÉTAIRES COMPARÉES: LES CAS DE PARIS ET SÃO PAULO}

\section{Ursula Dias Peres, Camille Allé}

Mots-clés: Finances publiques; processus budgétaire; analyse comparative; Paris; São Paulo.

Cet article compare la structure et le processus budgétaires des villes de São Paulo et Paris entre 2008 et 2018 . Il permet de comprendre les décisions budgétaires et contribue à la littérature sur les budgets publics, davantage centré sur les niveaux nationaux et fédéraux. Dans la mesure où le processus budgétaire est très technique et standardisé, de nombreuses similarités devraient être observées entre ces deux cas très différents. L'article décrit les similarités des structures et des processus budgétaires des deux villes. Il montre, par exemple, que dans les deux cas l'incrémentalisme budgétaire explique l'évolution d'une part du budget (la base), comme la théorie le prévoit. Néanmoins, le papier montre aussi des différences importantes entre ces deux cas aux macro-institutions très différentes (Etat fédéral versus Etat unitaire), aux meso-institutions semblables (organisation des institutions municipales, politiques publiques municipales), mais des règles budgétaires distinctes qui génèrent des différences importantes dans les processus budgétaires, ainsi que certaines divergences dans les résultats. 